\title{
The ON-Alpha Ganglion Cell of the Cat Retina and its Presynaptic Cell Types
}

\author{
Michael A. Freed and Peter Sterling \\ University of Pennsylvania Medical School, Department of Anatomy, Philadelphia, Pennsylvania 19104
}

\begin{abstract}
Anatomical circuits converging onto the $\mathrm{ON}$-alpha $(\mathrm{Y})$ ganglion cell were studied by computer-assisted reconstruction of substantial portions of 2 alpha cells from electron micrographs of serial sections. The alpha cells in the area centralis were labeled by a Golgi-like retrograde filling with horseradish peroxidase, and certain presynaptic amacrine processes were labeled by uptake of ${ }^{3} \mathrm{H}$-glycine. About 4400 synapses contacted the alpha cell. Eighty-six percent were from amacrine cells; the rest were from bipolar cells. About one-quarter of the amacrine synapses were specifically labeled by ${ }^{3} \mathrm{H}$-glycine and probably belong to the $\mathrm{A} 4$ amacrine. The bipolar inputs were provided by several types: cone bipolar $\mathrm{CBb}_{1}(85 \%)$, cone bipolar $\mathrm{CBb}_{5}(2 \%)$, the rod bipolar $(5 \%)$, and some unidentified cone bipolars $(11 \%)$. Contacts from each type occurred in specific strata, with the consequence that they tended to form spots or annulli over the alpha dendritic field.
\end{abstract}

The $\mathrm{CBb}$, bipolars formed a moderately dense array $(8000$ / $\mathrm{mm}^{2}$ ), with a nearest-neighbor distance of $8.6 \pm 1.3 \mu \mathrm{m}$. Most members of the array $(84 \%)$ contacted the alpha cell, providing 1-7 synapses (average, $2.7 \pm 1.6$ ). The placement of contacts from an individual CBb, followed certain rules: they were restricted to a parent branch of the alpha arbor or to 2 daughter branches, but almost never crossed a branch of the alpha arbor. The synaptic territory of an individual $\mathrm{CBb}$, was not shared with other $b_{1} s$ (or cone bipolars of any sort), although it was shared with amacrine contacts. Rod bipolar cells also formed a very dense array $\left(54,500 / \mathrm{mm}^{2}\right)$ in the alpha dendritic field, but only a few of these $(3 \%)$ contacted the alpha cell.

The concentric receptive field of the $\mathrm{CBb}_{1}$, combined with the spatial organization of its array, is used to predict the $\mathrm{CBb}_{\text {, }}$ contribution to the alpha cell receptive field; this contribution resembles the spatial and temporal organization of the alpha receptive field itself.

The ON-alpha ganglion cell of the cat retina is a specific type of neuron easily recognized by its large soma $(30 \mu \mathrm{m})$ and widely radiating dendrites, which, in the area centralis, span $180 \mu \mathrm{m}$ (Boycott and Wässle, 1974). It is known to have "Y"-type physiological properties (Enroth-Cugell and Robson, 1966; Peichl

\footnotetext{
Received June 16, 1987; revised Oct. 23, 1987; accepted Oct. 26, 1987.

This work was supported by NIH Grants EY00828, EY01583, and a training grant to M.A.F. (T32EY07035). We thank Dr. Barbara McGuire for good advice and Robert G. Smith for helpful discussions as well as software design. Thanks to Sam Hong, Donna Heaney, and Keith Bickel for technical support.

Correspondence should be addressed to Michael A. Freed, Building 36, Room 2C02, National Institutes of Health, Bethesda, MD 20892

Copyright (C) 1988 Society for Neuroscience $0270-6474 / 88 / 072303-18 \$ 02.00 / 0$
}

and Wässle, 1983; Saito, 1983; Fukuda et al., 1984; Stanford and Sherman, 1984), which include a wide receptive field with a brisk transient response to illumination over its center and an antagonistic surround response that overlaps the center (EnrothCugell and Pinto, 1972a, b; Cleland et al., 1973; Hickey et al., 1973). This cell type accounts for only about $2 \%$ of the axons leaving the retina, but it contributes importantly to the geniculostriate pathway, since this pathway contains neurons with physiological properties similar to, and presumably derived from those of the alpha cell (Hoffmann and Stone, 1971; Stevens and Gerstein, 1976; Mullikin et al., 1984; Sherman, 1985).

The ON-alpha receptive field properties are thought to arise, at least in part, from interneuronal circuits that connect the ganglion cell to photoreceptors. Anatomical studies showed numerous synaptic inputs from amacrine and cone bipolar cells (Kolb, 1979; Watanabe et al., 1985), but the types of bipolar and amacrine cells that provided these inputs were not determined, so it was not clear from these studies how such inputs contribute to the receptive-field structure. In order to identify the cell types contributing synaptic input to the ON-alpha cell, we reconstructed, from electron micrographs of serial sections, substantial portions of $2 \mathrm{ON}$-alpha cells in the area centralis, each from a different retina. We located all identifiable synaptic contacts on the dendrites and traced many back to axon stalks, which permitted identification of the parent neurons. It was found that the $\mathrm{ON}$-alpha cell receives numerous inputs from an array of type $b_{1}$ cone bipolar cells, and a lesser number of inputs from other types of bipolar cell. We explain, on the basis of this finding, how type $b_{1}$ input may contribute to the ON-alpha cell's Y-type receptive-field properties.

\section{Materials and Methods}

Two cats were used. An animal was anesthetized with thiopental (40 $\mathrm{mg} / \mathrm{kg}$ ) and held in a stereotaxic frame. An eye was stabilized by a ring sewed to the conjunctiva. We identified the optic disc with an ophthalmoscope and impaled its center region, which was devoid of blood vessels, with a glass micropipette inserted through the guide tube of a Levick-type micromanipulator. The pipette contained 30\% HRP (Sigma type III) in $2 \%$ dimethyl sulfoxide. About $1 \mu \mathrm{l}$ of this solution was injected by a small, motorized pump (Pi-Pump, W.P. Industries) over an interval of about $1 \mathrm{hr}$.

Anesthesia was maintained for the next $20 \mathrm{hr}$; at the end of this period, ${ }^{3} \mathrm{H}$-glycine $(100 \mu \mathrm{Ci}$ in $10 \mu \mathrm{l})$ was injected into the vitreous using the Levick-type manipulator. An hour later the cat was overdosed with anesthetic and perfused through the aorta with $2 \%$ paraformaldehyde and $2 \%$ glutaraldehyde in $0.1 \mathrm{~m}$ phosphate buffer $(\mathrm{pH} 7.4)$. The injected eye was hemisected after a $12 \mathrm{hr}$ soak in the aldehyde mixture. The central area was excised, pinned flat, and reacted in 2,4-diamino benzidine for $20 \mathrm{~min}$; the reaction was intensified with cobalt chloride (Adams, 1977). The tissue was then stained en bloc with $1 \%$ uranyl acetate in $70 \%$ methanol for $1.5 \mathrm{~h}$, dehydrated, infiltrated with Epon, sandwiched between 2 vinyl slides, and cured in an oven. 


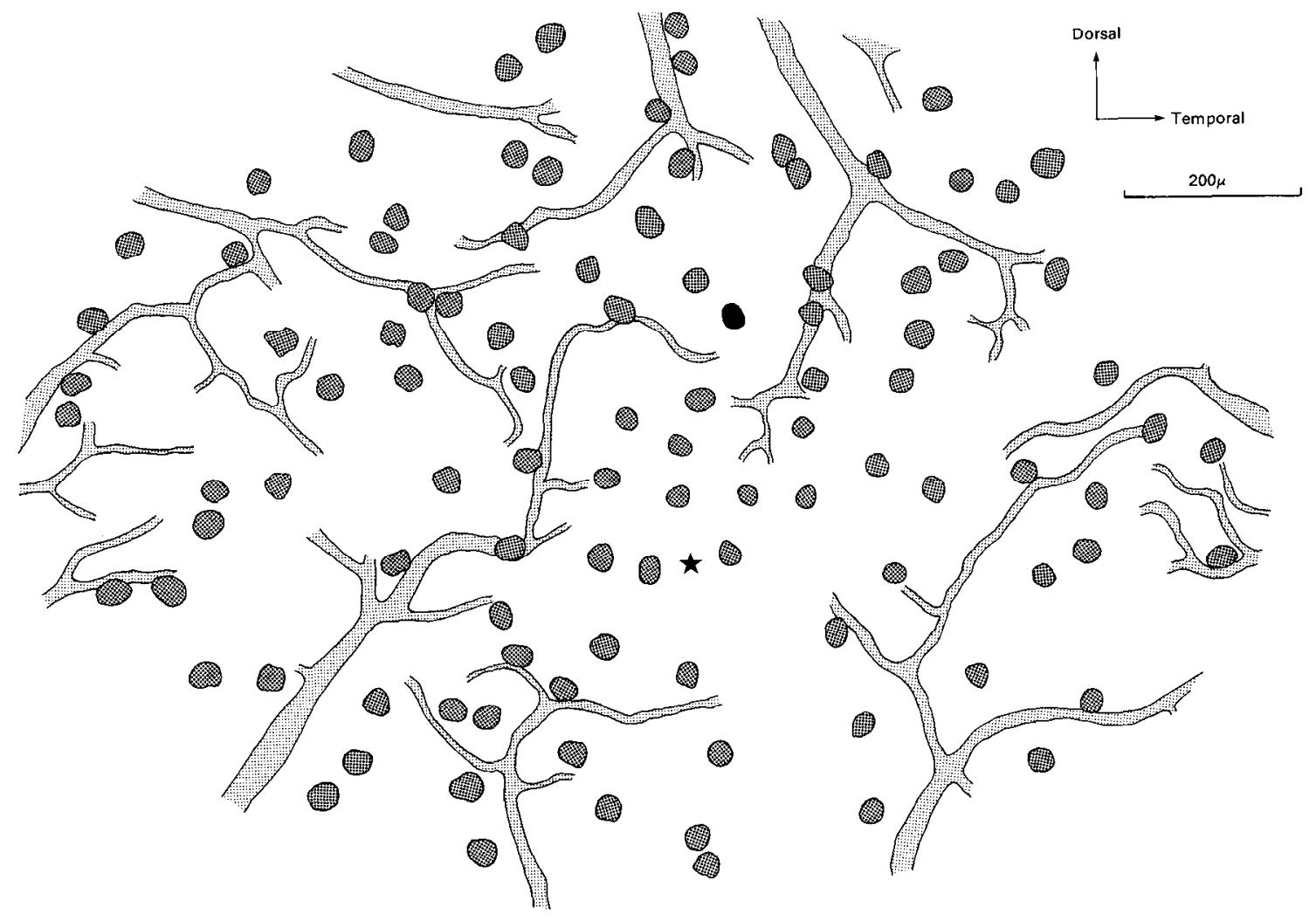

Figure 1. One-hundred and three alpha cells (ON and OFF) are present in the area centralis, an area about $1 \mathrm{~mm}$ high and $1.5 \mathrm{~mm}$ wide, bounded by the 3000 ganglion cell $/ \mathrm{mm}^{2}$ isodensity line (Stone, 1965). The region is devoid of superficial blood vessels, but marked, as shown, by deep vessels that radiate toward the center of the area centralis (*). Vessels at the center are not apparent because they course toward the choroid. HRPfilled ON-alpha cell 1 (dark) was selected for detailed analysis.

The embedded tissue was removed from between the vinyl slides and glued onto one end of an Epon cylinder. This cylinder had an image conduit embedded along its axis so that HRP-filled cells within the tissue could be viewed under a $100 \times$ oil-immersion objective when a microscope condenser was brought close to the other end of the image conduit. The plastic cylinder could also be inserted into a microtome chuck and thus the tissue could be alternately sectioned and viewed in the microscope.

An ON-alpha cell filled with a Golgi-like stain was selected from the area centralis of each retina. The cell body was drawn using a camera lucida. The layer of ganglion cell bodies was then cut away on the microtome to better reveal the dendritic tree. We drew this also in detail and then cut a serics of 220 ultrathin sections tangential to the arbor that completely included it. The sections were $0.075 \mu \mathrm{m}$ thick in one series and $0.09 \mu \mathrm{m}$ thick in another.

Autoradiography. Most of the radiocompound in the tissue $1 \mathrm{hr}$ after injection was still ${ }^{3} \mathrm{H}$-glycine (Freed et al., 1987). To visualize the distribution of this compound, we performed autoradiography on the series of $0.09-\mu \mathrm{m}$-thick sections by the method described by Davis et al. (1979). The ribbons of sections were laid down on celloidin-coated glass slides. The sections were then coated with carbon, dipped in Ilford L-4 emulsion, exposed for $49 \mathrm{~d}$, and developed in Kodak D-19. The celloidin-section-carbon-emulsion sandwich was stripped from the slide and placed on a slottcd Formvar-coated grid. The celloidin was dissolved away with amyl acetate, exposing the sections, which were then stained with lead citrate and uranyl acetate.

Reconstruction of the alpha cell. Each section through an alpha cell was photographed at $1400 \times$ in the EM. For one cell (\#1), this required 4 overlapping pictures to cover a full diameter of the dendritic arbor; for the other cell (\#2), this required 2 overlapping pictures to cover a full radius. Prints at a final magnification of $3700 \times$ were viewed under a dissecting microscope to identify the stained alpha cell profiles. The cell was reconstructed by tracing all the profiles in one section onto an acetate sheet and aligning successive sheets on a cartoonist's jig (see Stevens ct al., 1980b). The synaptic contacts were also identified and entered on the acetate sheets. The tracings were digitized with a graphics tablet and transmitted to a PDP 11/34 computer (Digital Equipment). The computer represented the cell as it would appear from different points of view by removing hidden lines and displaying both the cell and the synapses on either an X-Y plotter or a video terminal. In order to measure the surface area of an alpha cell, the perimeters of its profiles were summed for all sections and multiplied by the section thickness. To compare the alpha cell to another type of ganglion cell, the ON-beta, we measured membrane area from digitized sections of an ON-beta cell previously described by McGuire et al. (1986).

\section{Results}

\section{Location of reconstructed cells}

The area centralis was identified in the flat-mounted retina by the absence of superficial blood vessels. Ganglion cell somas of all types were stacked in tiers of 2 or 3 . Alpha cells were the most frequently filled cell type and had a peak density of about 135 cells $/ \mathrm{mm}^{2}$, in agreement with the peak density measured by Wässle et al. (1981).

Alpha cell 1 was chosen from the first retina because it was particularly well filled and free of overlapping processes from other ganglion cells. The soma was located about $300 \mu \mathrm{m}$ dorsal to the center of the area centralis (Fig. 1). The soma diameter, measured in 2 orthogonal dimensions, was about $27 \mu \mathrm{m}$, and the average dendritic field diameter was about $170 \mu \mathrm{m}$-typical dimensions for an alpha cell of the area centralis (Boycott and Wässle, 1974). Cell 2 was chosen from a second retina for its lighter staining, which allowed better resolution of synaptic junctions in the EM, although the finest dendrites could not be discerned in the light microscope. The soma lay about $150 \mu \mathrm{m}$ 


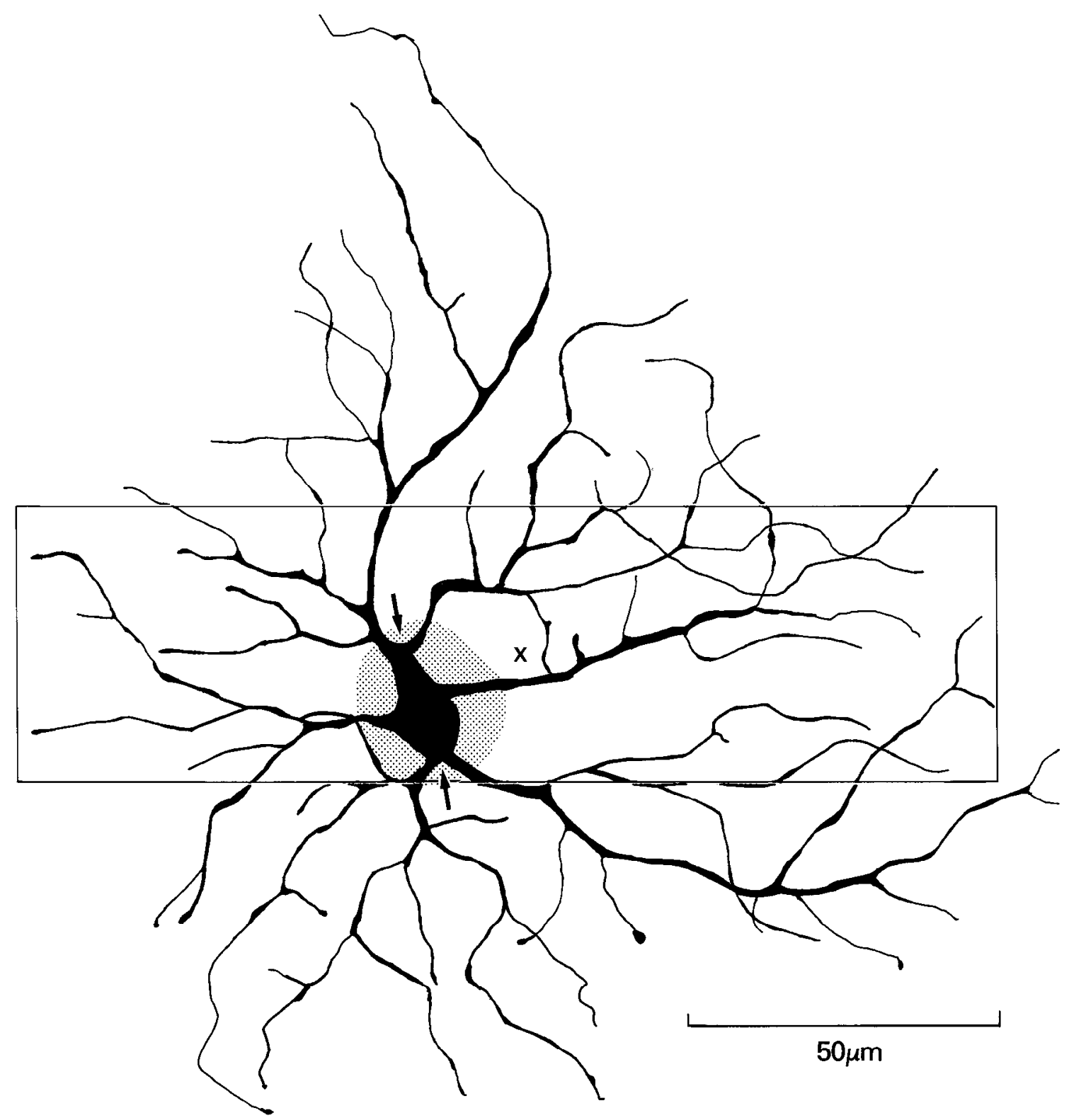

Figure 2. Camera lucida drawing of the filled $\mathrm{ON}$-alpha cell 1. The dendrites and a portion of the soma (dark) were drawn after the soma was cut away. The center of the soma (shaded) was about $20 \mu \mathrm{m}$ from the center of the dendritic field $(x)$. Two primary dendrites, at the top and bottom of the soma (arrows) are not apparent in this drawing since they course orthogonal to the plane of the paper, and each gives rise to 2 secondary dendritic branches. A swath across one diameter of the dendritic field was reconstructed (rectangle).

dorsal to the area centralis. The soma diameter was about 25 $\mu \mathrm{m}$ and the average dendritic field diameter about $150 \mu \mathrm{m}$. Alpha cell 1 was studied in greatest detail and is discussed first.

\section{Alpha cell 1}

Light microscopy. Cell 1, viewed in the light microscope (Fig. 2), had a radiating, planar arborization that covered about 22,300 $\mu \mathrm{m}^{2}$ of retina. The soma was close to the center of the dendritic field, being eccentric to the dendritic field's center of mass by about $20 \mu \mathrm{m}$. The cell showed 4 thick $(3 \mu \mathrm{m})$ primary branches extending vertically from the soma; these were foreshortencd in the tangential view, so that the secondary branches appeared at first glance to derive directly from the soma.

Electron microscopy. We reconstructed from the series of electron micrographs a swath about $50 \mu \mathrm{m}$ wide extending across one full diameter of the dendritic field (Fig. $3 A$ ) and covering about $9000 \mu \mathrm{m}^{2}$ of the retina (about $40 \%$ of the dendritic field). The EM reconstruction closely resembled the light microscope drawing of the same region. There was some compression along the direction of cutting, probably due to the mechanics of microtomy. A few fine dendritic branches that had been missed in the light microscope were found in the EM reconstruction; these did not enlarge the dendritic field. About 50 cylindrical thorns protruded from the reconstructed dendrites. These thorns were about $0.5 \mu \mathrm{m}$ long and $0.1 \mu \mathrm{m}$ in diameter and were not seen in the light microscope. In some cases, a fine process bifurcated into 2 thorns, forming a more complex appendage. Thorns have been found before in electron micrographs of alpha and beta cells (Watanabe et al., 1985; McGuire et al., 1986).

Structure of dendritic arborization. The primary dendrites ascended almost vertically through strata 5 and 4 of the inner plexiform layer. Upon reaching stratum 3 , these turned hori- 
A

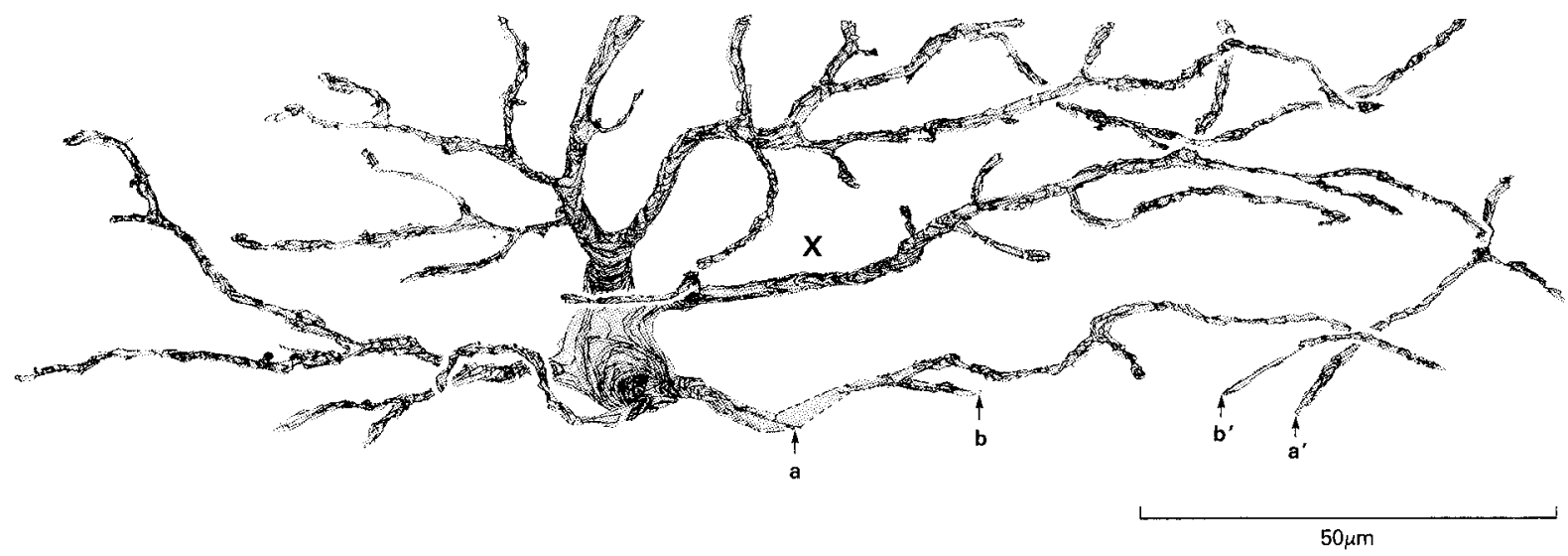

B

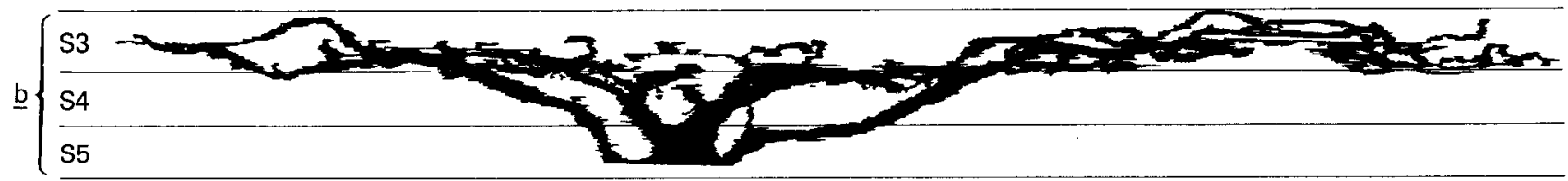

Figure 3. Reconstruction of alpha cell 1 contained within the swath indicated in Figure 2. $A$, Original tangential view. In this and subsequent figures, the center of the entire dendritic field is indicated $(\times)$. The dendritic segments connecting points $a, a^{\prime}$ and $b, b^{\prime}$ were omitted in the reconstructed swath, but were visible in the light microscope (compare with Fig. 2 ). $B$, the same reconstruction rotated $90^{\circ}$ to produce a radial view. The strata of the inner plexiform layer's sublamina $b$ are indicated $(S 3, S 4, S 5)$.

zontally and bifurcated repeatedly (Fig. $3 B$ ). Ultimately there were 9 orders of branching and a total of 121 branches, most of which undulated vertically within the confines of stratum 3 (Famiglietti and Kolb, 1976). The dendritic bifurcations occurred at irregular intervals, and this caused the branch length within a given branch order to vary widely (Table 1).

The diameter of the reconstructed dendrites varied widely within any given branch order, but the average branch diameter declined from the first- to third-order branches and then remained constant at about $1 \mu \mathrm{m}$ for the higher-order branches (Table 1). The diameter of parent and daughter branches at a bifurcation did not closely follow the "power law" suggested by Rall (1959). This law specified the relationship between parent $\left(D_{1}\right)$ and daughter $\left(D_{2}, D_{3}\right)$ diameters theoretically necessary to insure a good impedance match at a branch point:

$$
D_{1}^{3 / 2} /\left(D_{2^{3 / 2}}+D_{3}^{3 / 2}\right)=1 \text {. }
$$

For cell 1 the average value of this ratio was $0.8 \pm 0.5$. Thus the parent branch was usually smaller in proportion to the daughter branches than specified by the power law, and the relationship between parent and daughter diameters varied considerably. This confirms Koch et al. (1982), who measured den- dritic diameters from light-microscopic drawings of Golgi-impregnated cells. Both findings suggest either that the impedance match at each branch point is not optimal or that the equation does not account accurately for the impedances in a dendritic tree.

Membrane area. The reconstructed dendrites had a membrane surface area of about $2040 \mu \mathrm{m}^{2}$. This gave an estimated membrane area for the whole dendritic tree of about $5100 \mu \mathrm{m}^{2}$, and when a spherical soma of $2290 \mu \mathrm{m}^{2}$ area was added, the total surface area of the whole cell was about $7400 \mu \mathrm{m}^{2}$. The ratio of the membrane area to a unit area of retinal surface was about 0.23 . This is considerably sparser coverage than is provided by the ON-beta cell. The ON-beta partially reconstructed by McGuire et al. (1986) had a membrane area of $466 \mu \mathrm{m}^{2}$ over a retinal area of $316 \mu \mathrm{m}^{2}$, resulting in an area of membrane per unit area of retinal surface of 1.5 , or about 8 times that of the alpha cell. This difference is partly explained by the beta cell's shorter average branch length, about $3.7 \mu \mathrm{m}$ versus about 10.8 $\mu \mathrm{m}$ for the alpha cell, which implies that the beta cell branches more frequently for a given length of dendrite. Another contributing factor is the beta cell's diffuse stratification: it branches in all strata of sublamina $b$ (S3-S5), which causes many branches

\begin{tabular}{lllllllllll}
\hline \multicolumn{1}{l}{ Table 1. Branch pattern of alpha cell } & & & & & & & & \\
\multicolumn{1}{l}{ Branch order } & $1^{\circ}$ & $2^{\circ}$ & $3^{\circ}$ & $4^{\circ}$ & $5^{\circ}$ & $6^{\circ}$ & $7^{\circ}$ & $8^{\circ}$ & $9^{\circ}$ \\
No. of branches & 4 & 8 & 14 & 17 & 19 & 36 & 11 & 10 & 2 \\
Average length $(\mu \mathrm{m})$ & 7.7 & 5.3 & 10.0 & 6.3 & 9.6 & 12.5 & 13.3 & 10.9 & 4.3 \\
SD $(\mu \mathrm{m})$ & 2.1 & 3.0 & 6.6 & 3.2 & 4.6 & 8.3 & 12.5 & 6.8 & 1.0 \\
Average diameter $(\mu \mathrm{m})$ & 2.9 & 1.3 & 1.2 & 1.0 & 1.0 & 0.8 & 0.9 & - & - \\
SD $(\mu \mathrm{m})$ & 1.3 & 0.5 & 0.6 & 0.4 & 0.4 & 0.2 & 0.1 & - & -
\end{tabular}

A branch was defined as a length of dendrite between bifurcations. The branch order was derived by adding branches made visible in the electron microscope to the light-microscopic drawing. The branch length was measured from the camera lucida drawing alone. The branch diameter was measured from the reconstruction in $3 \mu \mathrm{m}$ increments and then averaged. 

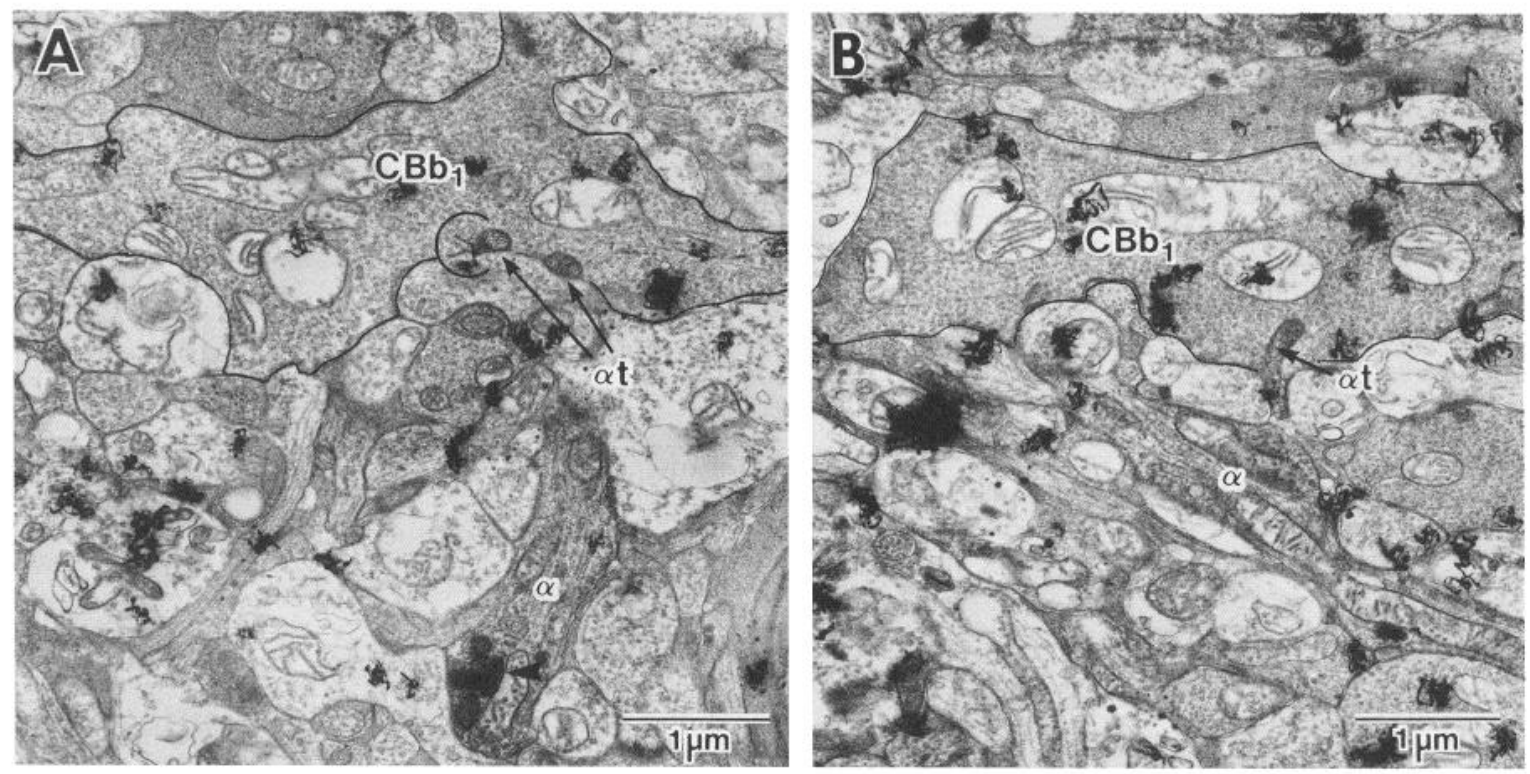

Figure 4. Electron micrographs of type $\mathrm{b}_{1}$ axons presynaptic to the alpha cells. $A$, Synaptic ribbons (circled) presynaptic to a darkly stained alpha thorn $(\alpha t)$. Two thorns, shown in cross section, invaginate the $b_{1}$ axon and, when followed through the series, lead to the alpha cell dendrite $(a)$, marked by granules of HRP reaction product (arrowhead) in its cytoplasm. $B$, Longitudinal section through an alpha cell thorn invaginating a $b_{1}$ axon terminal. Silver grains are present over the $b_{1}$ axon, but this is true for all types of cone bipolar axon in sublamina $b$ and does not implicate glycine as the transmitter (Cohen and Sterling, 1986).

to overlay one another, in contrast to the more narrowly stratified alpha cell.

Synaptic contact. Six hundred and fifty-eight synaptic contacts were found on the reconstructed dendrites of alpha cell 1 and, as noted by Stevens et al. (1980a), none were found on the soma. Most contacts were in strata 3 and 4 and few were in stratum 5 . We estimated that examination of the complete dendritic tree of alpha 1 would have revealed 1640 synaptic contacts. The density of these synaptic contacts was about $7 / 100 \mu \mathrm{m}^{2}$ of retinal surface and $32 / 100 \mu \mathrm{m}^{2}$ of membrane area $\left(36 / 100 \mu \mathrm{m}^{2}\right.$ in S3 and S4 only). The ON-beta ganglion cell reconstructed by McGuire et al. (1986) had a greater synaptic density over the retinal surface: about 70 synaptic contacts per $100 \mu \mathrm{m}^{2}$ retinal surface, or about 10 times that of the alpha cell. The ON-beta cell also had a greater synaptic density over its membraneabout $48 / 100 \mu \mathrm{m}^{2}-$ which, when multiplied by its greater membrane density over the retina, would result in the observed greater synaptic density over the retinal surface.

Two hundred nineteen of the synaptic contacts on the alpha cell (33\%) contained synaptic ribbons and were therefore considered to have arisen from bipolar axons; the remainder (67\%) arose from amacrines (Dowling and Boycott, 1966). We believe that some additional amacrine contacts may have been present but not identified because they tended to be obscured by the dark HRP reaction product in the alpha cell cytoplasm. Indeed, $\mathrm{ON}$-alpha 2 (see below), which was more lightly stained, had a higher percentage $(86 \%)$ of amacrine contacts. Kolb (1979) reported the fraction of amacrine contacts on an $\mathrm{ON}$-alpha cell to be $80 \%$ but Watanabe et al. (1985) reported $54 \%$. We believe the latter figure to be too low because their cell, like our cell 1, was darkly stained, and also because Watanabe et al. (1985) did not require a ribbon to identify a bipolar, but only a cluster of vesicles, and this would tend to increase the fraction of contacts classed as bipolar. Given, however, that the 4 cells studied come from different animals, different eccentricities, and were studied with somewhat different methods, the source of variation between the 4 results cannot be determined.

Inputs from type $b_{1}$ cone bipolar cells. We traced each bipolar process contacting the alpha cell through the series back to the parent axon to determine its type. One hundred seventy-nine of these contacts ( $80 \%$ of all bipolar contacts) were traced to axons of type $b_{1}$. Type $b_{1}$ is distinctly pale, though the finer terminations can be somewhat darker, and is filled with numerous synaptic vesicles (Fig. 4). The axon stalk, narrow in stratum 3 , dilates distinctively near stratum 4 , and emits multiple thick processes that form a clawlike arbor (McGuire et al., 1984; Cohen and Sterling, 1986; type CB5 of Kolb et al., 1981). The $b_{1}$ contacts to the alpha cell in stratum 3 were usually from the main axon stalk; the contacts in stratum 4 , however, were often from the thinner processes of the axon arborization.

The $b_{1}$ contacts were dyadic; that is, they contacted 2 processes at the same site, one being the alpha cell and the other usually an amacrine process. Most $b_{1}$ contacts were on dendrites, but 23 were on dendritic thorns. Often the thorns invaginated the $b_{1}$ axon stalk but nevertheless received contact near the surface of the axon (at the base of the thorn). In 3 cases a thorn was contacted twice by the same $b_{1}$ process, both at the base and the tip of the thorn. Alpha cell thorns were not observed to invaginate any other type of process.

Structure of the $b_{1}$ axon array. Seventy-four $\mathrm{b}_{1}$ axons were present in the reconstructed swath of the $\mathrm{ON}$-alpha dendritic field (Fig. 5). The axons had a mean distance to their nearest neighbors of $8.6 \pm 1.3 \mu \mathrm{m}$. The ratio of this mean to the standard deviation was 6.6 , which indicated a substantial regularity of spacing, greater than for many other retinal cell types (Wässle and Riemann, 1978; Table 4 of Sterling, 1983; Vaney, 1985; Freed et al., 1987). The density of $b_{1}$ axons over this region was about $8000 / \mathrm{mm}^{2}$. Since the tangential spread of the $b_{1}$ axon 


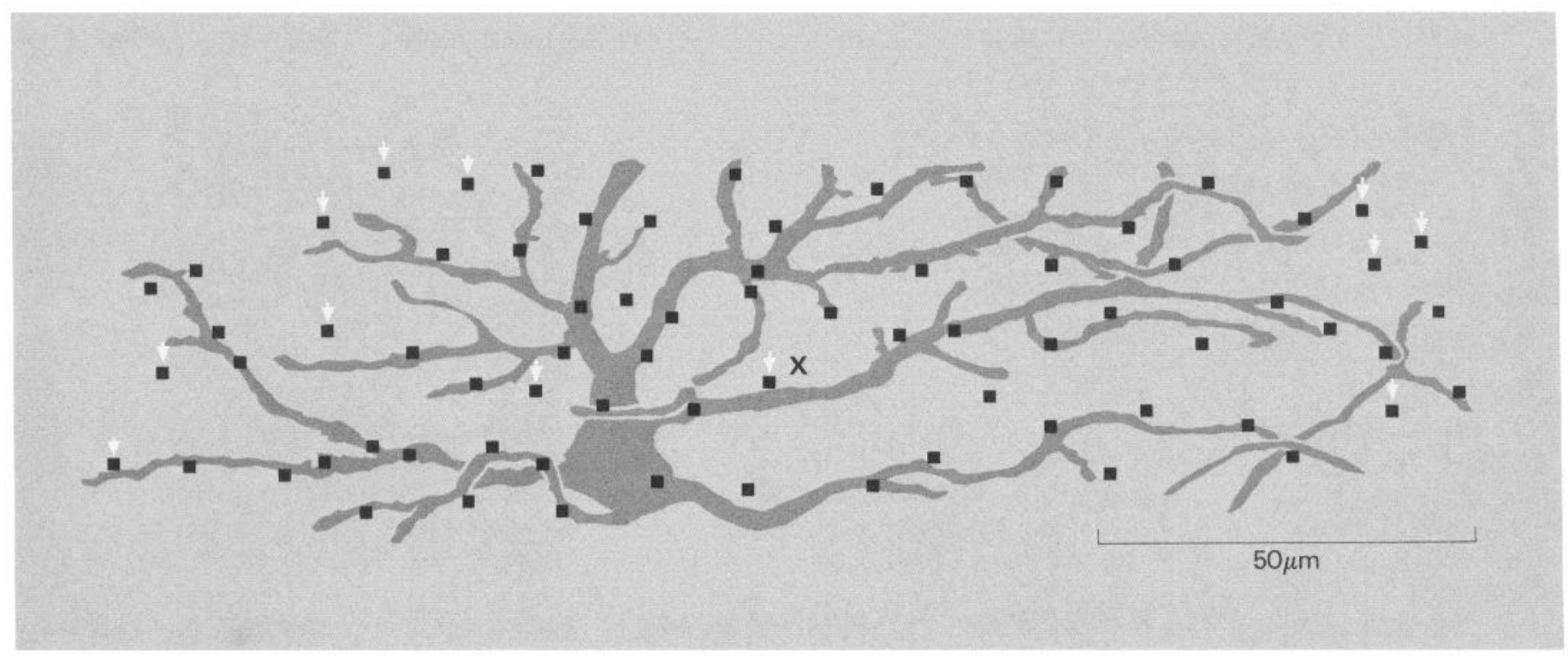

Figure 5. The locations of $74 b_{1}$ axon stalks mapped from a single section at the $a / b$ border. The stalks form a regular array across the reconstructed area of the dendritic field of alpha 1 . Sixty-two members of this array (84\%) contact the alpha cell. Twelve $b_{1}$ axons were not found to make contact on the alpha cell (downward arrows).

arbor in the area centralis is about $16 \mu \mathrm{m}$ (Sterling et al., 1987), the "coverage factor" (density $\times$ area; Wässle and Riemann, 1978) of a b axon was 1.6 .

Convergence and divergence of the $b_{1}$ axons. Of the $74 \mathrm{~b}_{1}$ axons whose stalks lay within the dendritic field, $62(84 \%)$ contacted the alpha cell. None of the $b_{1}$ axons whose stalks lay outside the dendritic field made contact, even though their arbors overlapped the dendritic field. We estimate that about $150 b_{1}$ axons would converge on an entire $\mathrm{ON}$-alpha cell. The divergence (div) of a single $b_{1}$ axon to an ON-alpha cell was estimated from the density $(A)$ of the ON-alpha cell (about $45 \%$ of all alpha cells in the region studied, or about $60 / \mathrm{mm}^{2}$; Wässle et al., 1981), the density $(B)$ of the $b_{1}$, and the value of the convergence (conv) according to equation (2) (Freed et al., 1987).

$$
\operatorname{div}=(\operatorname{conv})(A) /(B) \text {. }
$$

Thus each $b_{1}$ axon diverges to about 1.2 alpha cells.

Number and location of contacts from individual $b_{1}$ axons. Each type $b_{1}$ axon provided from 1 to 7 contacts to the ONalpha cell (average: $2.7 \pm 1.6$ ). The number of contacts contributed by an individual type $b_{1}$ varied greatly within any region of the dendritic field, but in general type $b_{1}$ axons in the periphery of the alpha cell's dendritic field contributed fewer contacts than those near the dendritic field center.

Individual $b_{1}$ axons directed their contacts to only one side of a branch point (Fig. $6 A$ ). That is, the axon almost always ( 59 of 62 cases) made synaptic contact on either one or both daughter branches of the alpha cell or on the parent branch, but not on both the parent and daughters. Three axons were exceptions to this rule: each contributed several synapses to one side of a branch point and a single contact to the other side. In 2 cases, when 2 alpha dendrites crossed, the contacts of a single $b_{1}$ were on branches of the same order but different parents. The contacts from an individual $b_{1}$ were never interposed with those of any other $b_{1}$. Thus, each $b_{1}$ had its own territory on the alpha dendrites.

Inputs from other cone bipolar cell types. Twenty-nine contacts to the $\mathrm{ON}$-alpha cell were traced to bipolar processes that were distinctly darker than those of the $b_{1}$ and of 2 morphologies. Five of these contacts were from large varicosities $(3 \mu \mathrm{m}$ diameter) with extremely dark cytoplasm that were concentrated at the junction of strata 4 and 5 (Fig. $7 B$ ). We could not trace the processes back to an axon stalk because the connections between these varicosities were extremely fine and tortuous. However, they clearly resembled in size, electron density, and stratification the varicosities of a wide-field cone bipolar, type $\mathrm{b}_{5}$ (Cohen and Sterling, 1987), which corresponds to Kolb et al.'s (1981) type CB8, which was described from Golgi inpregnations. The remaining 24 contacts to the alpha cell were from fine processes, less dark than the $b_{5}$ varicosities (but darker than type $\left.b_{1}\right)$, that were concentrated at the junction of strata 3 and 4 (Fig. $7 A$ ). These fine processes, which contained mitochondria wrapped around each other, were traced to narrow axonal stalks that dilated only moderately in sublamina $b$. These processes might belong to any or all of the 3 remaining types of cone bipolar axon in sublamina $b$, types $\mathbf{b}_{2}-\mathrm{b}_{4}$ (McGuire et al., 1984; Cohen and Sterling, 1987).

All the $b_{5}$ varicosities contacted the shaft of a single primary dendrite (Fig. 8). The fine processes made dyadic synapses on dendritic shafts and on 2 thorns. Contacts from both types were located between clusters of contacts from individual $b_{1}$ cone bipolars (compare Figs. $6 A$ and $8 A$ ). Thus the territories established by $b_{1}$ axon terminals on the alpha dendrites were not invaded by contacts from dark cone bipolars.

Inputs from the rod bipolar cell. Eleven contacts to the reconstructed portion of alpha cell were traced to axons identified as rod bipolar by their simple bag-shaped axon terminal with a cytoplasm darker than that of any cone bipolar (Ramon y Cajal, 1892; Kolb 1979; McGuire et al., 1984) (Fig. 9). Most rod bipolar contacts occurred in stratum 3 , with only one in stratum 4 and none in stratum 5. Each contact was dyadic: at a single synaptic site, the rod bipolar was presynaptic to both the alpha cell and almost invariably to an amacrine that returned a synapse onto the rod bipolar. 

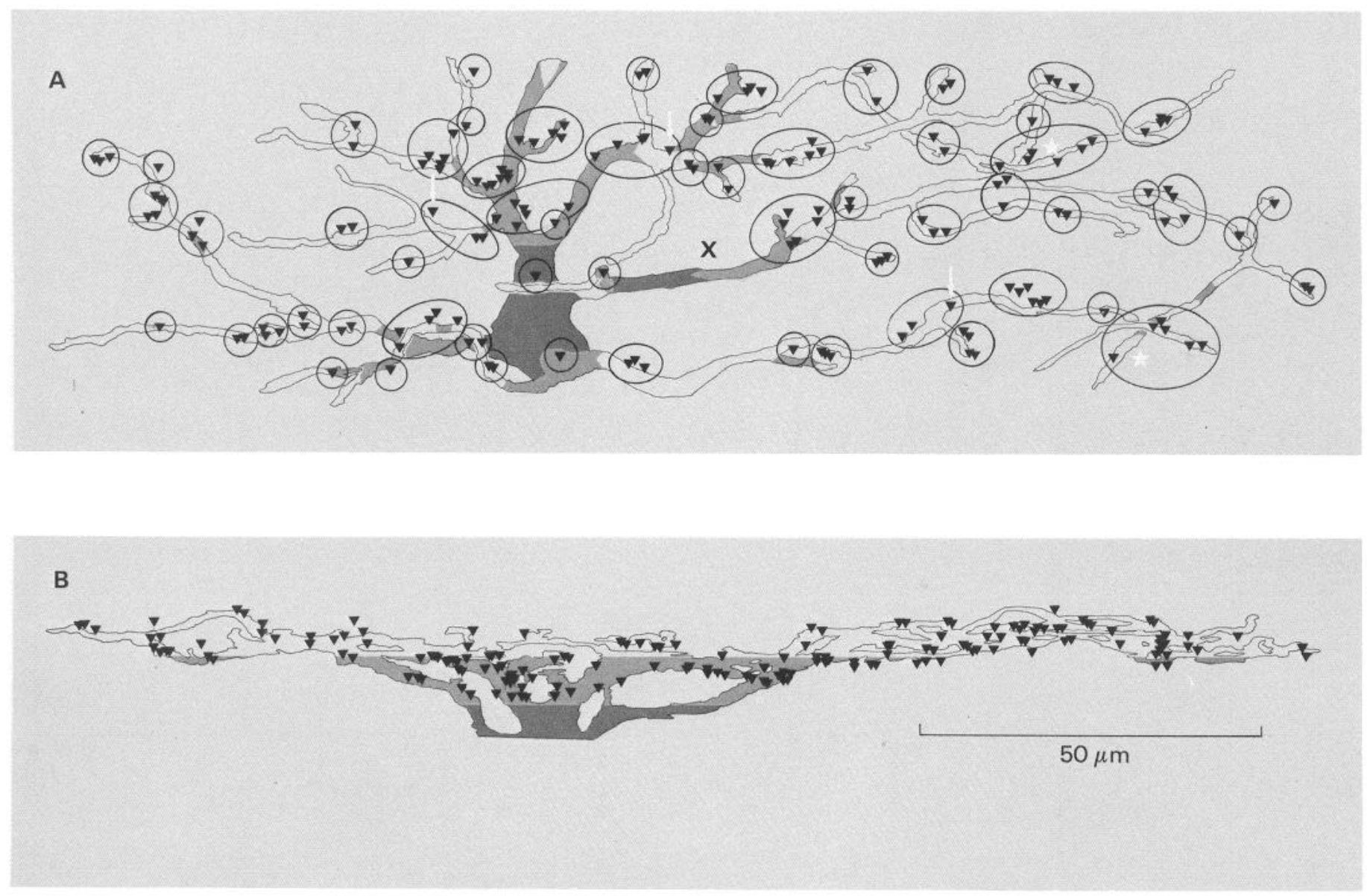

Figure 6. Distribution of $\mathrm{b}_{1}$ contacts (triangles) to the reconstructed dendrites of alpha 1 . In this and subsequent reconstructions, shading indicates dendritic stratification. $A$, Tangential view. Each set of circled contacts are from a single $\mathrm{b}_{1}$. Contacts from a single $\mathrm{b}_{1}$ were almost always on one side of a branch point; the few exceptions to this rule are marked (by an arrow.). Where contacts from a single $b_{1}$ distributed to 2 branches, these branches were almost always daughter branches of the same parent dendrite, 2 exceptions are indicated (*). $B$, Radial view. Contacts of $b_{1}$ were limited to strata 3 and 4.

Convergence and divergence of the rod bipolar axons. Very few of the rod bipolar axons that could potentially contact the alpha cell actually did so. In the reconstructed region, the rod bipolar axon terminals, including "supernumerary" terminals (Freed et al., 1987), formed a dense array, with a nearest-neighbor distance of $3.2 \pm 0.7 \mu \mathrm{m}$ and a density of $54,500 \mathrm{~mm}^{2}$. Thus, about 500 rod bipolar axons were within the reconstructed area, but only $11(2 \%)$ contacted the alpha cell, each rod bipolar axon providing a single contact. The estimated convergence of rod bipolar cells on the entire alpha cell of about 28 can be substituted into equation (2) to derive a divergence of about $0.03 \mathrm{ON}$-alpha cells contacted by an individual rod bipolar cell. This indicates that only about one in every 30 rod bipolar cells contacts an $\mathrm{ON}$-alpha cell.
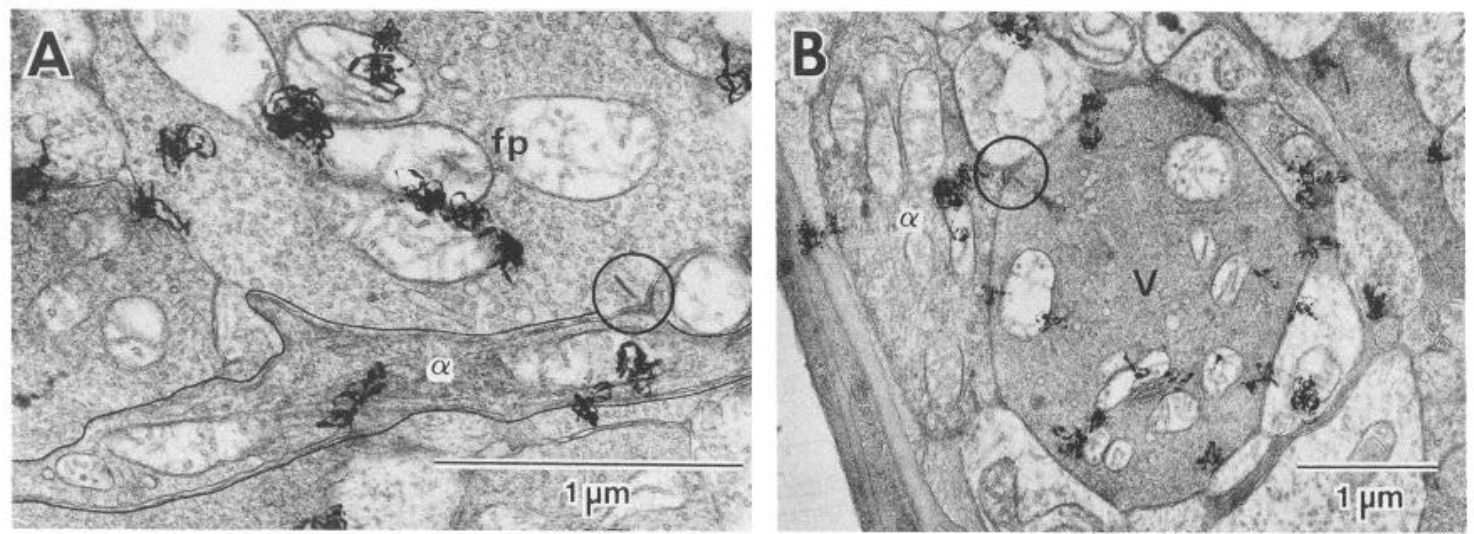

Figure 7. Electron micrographs of dark cone bipolar axons. $A$, Fine process $(f p)$ with a moderately dark cytoplasm is presynaptic to the alpha cell at a ribbon (circled). $B$, Large cone bipolar varicosity $(V)$ with a dark cytoplasm (probably type $b_{5}$ ) is presynaptic to a primary alpha dendrite. 

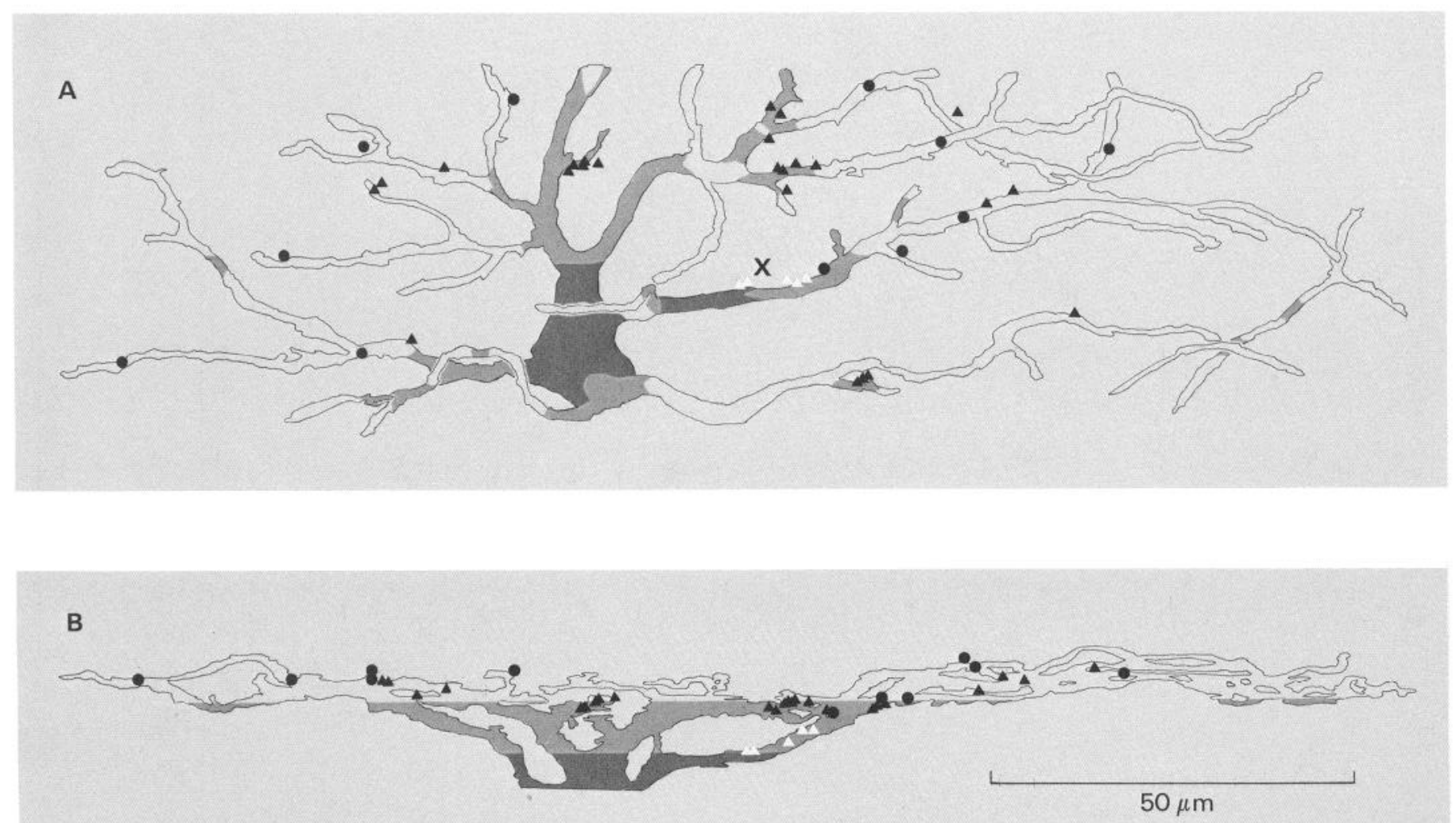

Figure 8. Distribution of contacts from dark cone bipolar and rod bipolar axons presynaptic to the reconstructed dendrites of alpha cell 1 . $A$, Tangential view. Five contacts from presumed type $b_{5}$ bipolars (white triangles) are at the dendritic field center. Contacts from fine cone bipolar processes (black triangles) form an annulus at intermediate distances around the dendritic field center and soma. Eleven rod bipolar contacts (dots) are distributed mainly to distal regions. $B$, Radial view. Contacts from cone bipolar varicosities lie at the border of strata 4 and 5 , contacts from fine processes are concentrated at the border of strata 3 and 4 .

Stratified and annular distribution of bipolar input. The contacts to the ON-alpha cell from all bipolar types other than type $b_{1}$ were fairly narrowly stratified. Thus, as noted, $b_{5}$ contacts were at the S4-S5 border, contacts from fine cone bipolar processes were at the $\mathrm{S} 3-\mathrm{S} 4$ border, and rod bipolar contacts were mainly in S3. A correlate of these laminar distributions was that each of the 3 sets of bipolar synapses formed a spot or an annulus concentric with the alpha cell dendritic field center and at progressively greater distances from it. This correlation arose from the distribution of alpha cell dendritic membranes in each stratum, which was annular about the dendritic field center. Type $b_{1}$ contacts were more broadly stratified in $\mathrm{S} 3$ and $\mathrm{S} 4$, and since alpha dendrites in these strata cover the dendritic field fairly completely, the $b_{1}$ contacts did not form a sharply defined annulus. However, type $b_{1}$ contacts on the alpha cell were absent in stratum 5, where dendrites at the center of the alpha dendritic field lie; thus $b_{1}$ contacts formed a disk with a hole in the center near the soma.

Inputs from amacrine cells. The 439 amacrine contacts on the reconstructed portion of the alpha cell were mainly from small varicosites with pale cytoplasm and a moderate number of synaptic vesicles (Fig. 10). The vesicles were usually clustered at the presynaptic membrane, and these contacts and densifications symmetrically distributed between the pre- and postsynaptic membrane. Contacts were always to dendritic shafts, which sometimes bore a slight convexity that indented the amacrine membrane. Amacrine contacts invaded the territories established by contacts from individual $b_{1}$ cone bipolars.

We distinguished amacrine processes that accumulated ${ }^{3} \mathrm{H}$ glycine in a specific fashion ( 8 or more silver grains in $10 \mathrm{sec}-$ tions) from those that showed only nonspecific accumulation (Fig. 11). Nineteen percent of the amacrine contacts on the alpha cell were from glycine-accumulating varicosities. These were distributed mainly in stratum 3 , with a few in stratum 4 and none in stratum 5 (Fig. 12). This stratified distribution of glycine-accumulating amacrine contacts formed, in the tangential plane, an annular distribution about the alpha cell's dendritic field center. The glycine-accumulating processes could not be traced to an identified type; however, they probably belong to type $\mathrm{A} 4$, since it is the only type with similar-appearing processes known to arborize at the junction of strata 2 and 3, to accumulate glycine, and to contact ganglion cells (Kolb, 1984; Pourcho and Goebel, 1985). The non-glycine amacrines provided contacts in strata 3 and 4 , with a few in stratum 5 , and thus showed a relatively even distribution across the dendritic field.

\section{Alpha cell 2}

Electron microscopy. Dendrites of cell 2 were reconstructed in a swath $70 \mu \mathrm{m}$ long, including a portion of the soma, which 

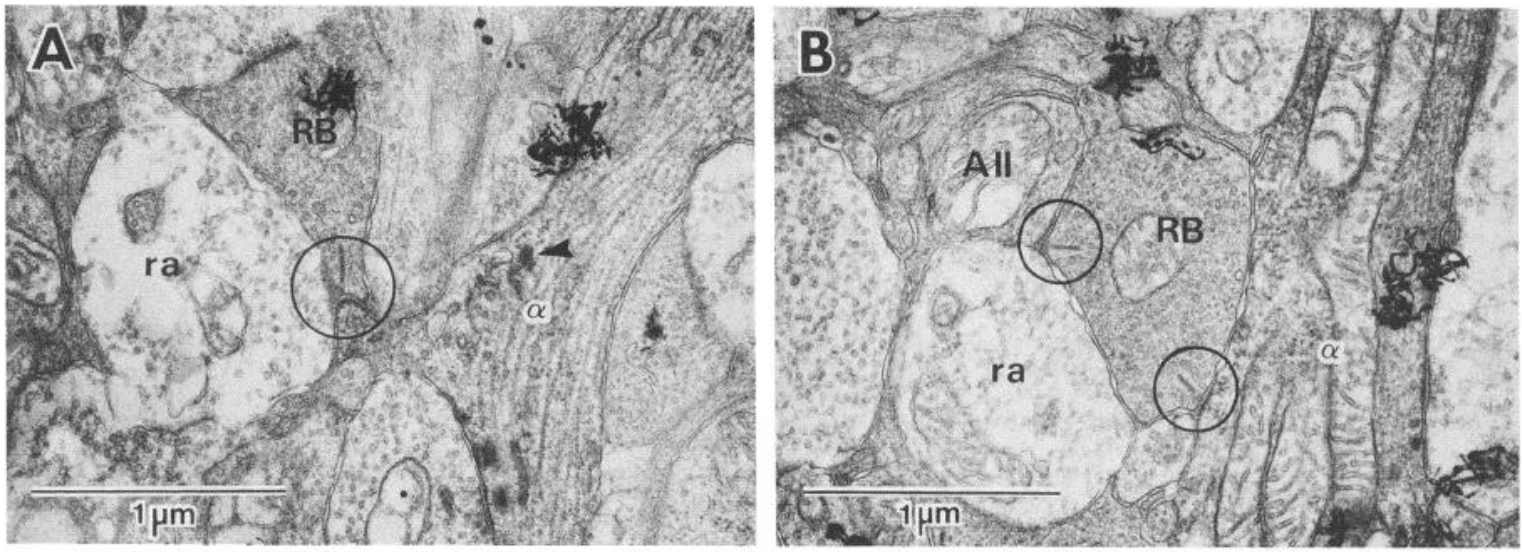

Figure 9. Electron micrographs of rod bipolar axons presynaptic to the alpha cell. $A$, Rod bipolar $(R B)$ presynaptic at dyad to both an alpha cell thorn $(\alpha t)$ and a reciprocal amacrine varicosity $(\mathrm{ra})$, which synapsed upon the rod bipolar in another section. The synaptic ribbon is circled. B, Rod bipolar presynaptic at dyad to alpha cell dendritic shaft and reciprocal amacrine. This rod bipolar is presynaptic, at another dyad, to an $A I I$ amacrine process and a reciprocal amacrine varicosity.

apparently spanned a full radius of the dendritic field (Fig. 13, $A, B)$. A circular dendritic field with this radius would cover about $16,000 \mu \mathrm{m}^{2}$. The reconstructed swath covered about 3200 $\mu \mathrm{m}^{2}$, or about $20 \%$ of the entire dendritic arbor. About 1500 $\mu \mathrm{m}^{2}$ of membrane was contained in the swath, giving a ratio of membrane area to retinal area of 0.48 ; thus, the arbor of cell 2 was denser than that of cell 1 . The arbor of cell 2 was also less stratified. The density, stratification, and size of the arbor of cell 2 are consonant with its location closer to the very center of the area centralis (Famiglietti and Kolb, 1976; Wässle et al., 1981).

We found 507 contacts on the dendritic arbor, giving a density of about $16 / 100 \mu \mathrm{m}^{2}$ of retinal surface, which appears similar to that found for alpha 1 when compared to the much higher density for the ON-beta cell. The density of contacts over the membrane, about $34 / 100 \mu \mathrm{m}^{2}$ of membrane area, was also almost identical to that for alpha 1.

Inputs from $b_{1}$ cone bipolar cells. The cytological appearance of type $b_{1}$ cone bipolars and their mode of contact on the thorns and dendritic shafts of cell 2 were entirely similar to those for cell 1. Type $b_{1}$ contributed 63 contacts to the reconstructed portion of cell 2 , and was the predominant bipolar input, contributing about $89 \%$ of the total bipolar contacts, a percentage similar to that of cell 1 (Table 2). These contacts were limited to strata 3 and 4, and avoided an area in the center of the dendritic field near the soma (Fig. 13, $C, D$ ).

Contacts from type $b_{1}$ cone bipolars were clustered to one side of a branch point as for cell 1 , with only one exception among 24 clusters. All clusters of $b_{1}$ contacts were from processes found to be continuous in stratum 4 . We could not follow all $b_{1}$ processes through stratum 3 to an axon stalk because of an intervening break in the series of sections, so it cannot be proven that each cluster arises from a single $b_{1}$ axon. However, the average number of contacts in each cluster (2.6) agreed closely with the average number of contacts from individual $b_{1}$ on cell 1 (2.7), which suggested that indeed each cluster was from an individual bipolar. In some cases, 2 groups of contacts were on opposite sides of the same stout dendritic branch, but no groups
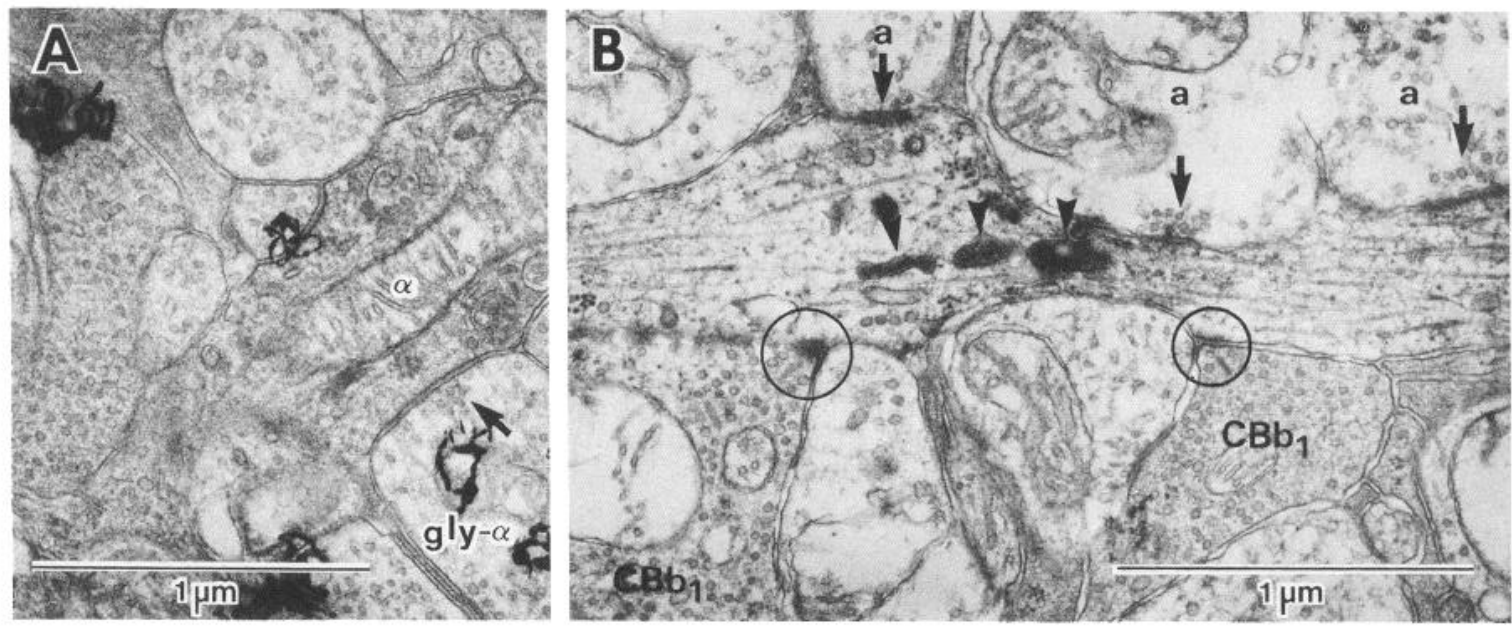

Figure 10. Electron micrographs of amacrines presynaptic to alpha cell. $A$, Autoradiogram showing 2 silver grains overyling a specifically labeled amacrine process $(g l y-a)$ that makes a symmetrical synapse (arrow) onto alpha cell $1(\alpha)$. B, Four amacrine processes $(a)$ presynaptic to alpha cell 2 . Two type $\mathrm{b}_{1}$ cone bipolar axons $\left(C B b_{l}\right)$ are also presynaptic to the alpha cell, each at a synaptic ribbon (circled). Arrowheads mark HRP reaction product. 


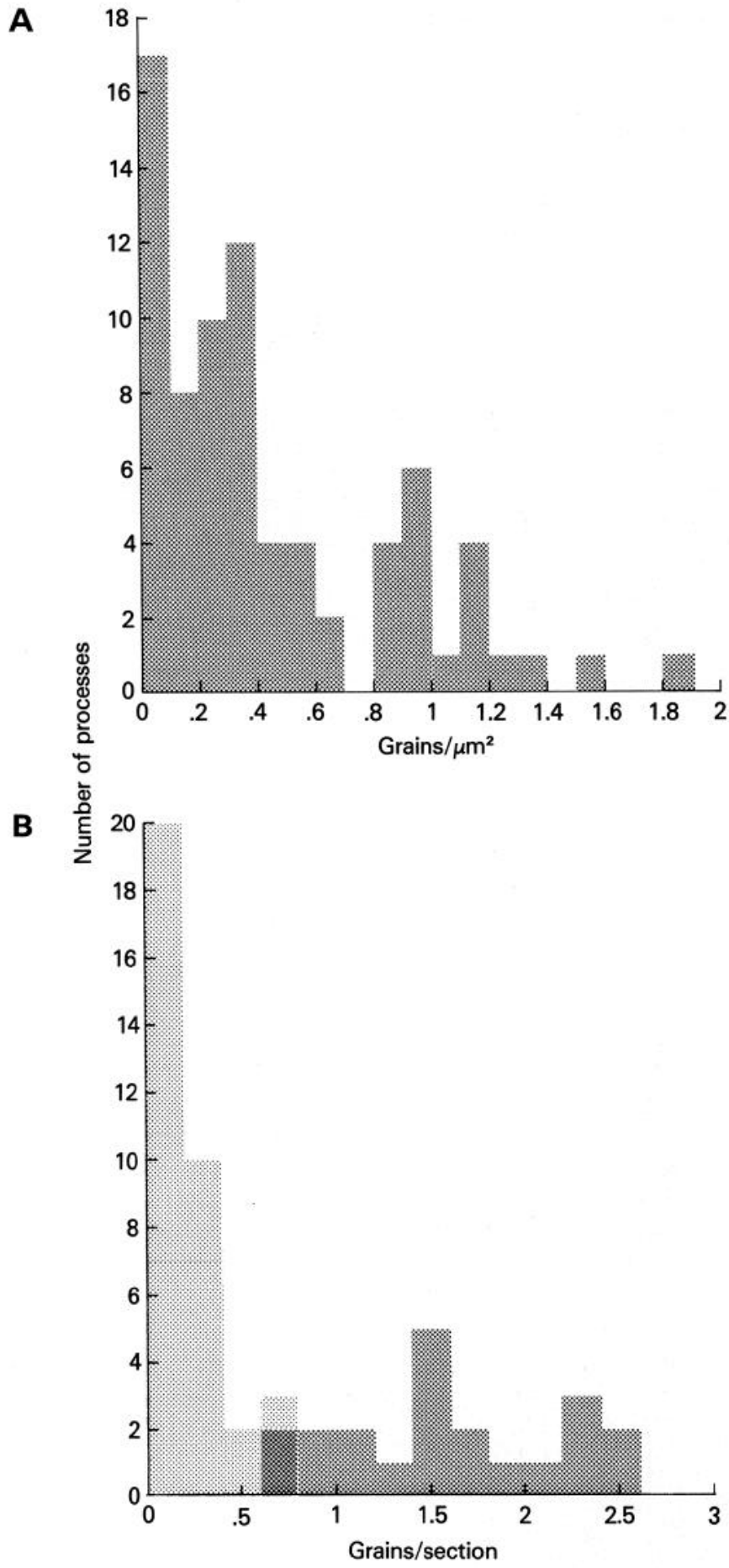

Figure 11. Grain density analysis. A, Distribution of processes randomly selected from the inner plexiform layer according to grain density. One population had fewer than 0.7 grains $/ \mu \mathrm{m}^{2}$ and was considered to be nonspecifically labeled. A second population had more than 0.8 grains $/ \mu \mathrm{m}^{2}$ and was considered to be specifically labeled. $B$, Distribution of amacrine processes presynaptic to the alpha cell according to the number of grains per section. Pale stippling indicates processes with fewer than 0.7 grains $/ \mu \mathrm{m}^{2}$; dense stippling, processes with more than 0.7 grains $/ \mu \mathrm{m}^{2}$. All amacrines processes with 0.8 or more grains per section had more than 0.7 grains $/ \mu \mathrm{m}^{2}$; thus every presynaptic amacrine with 4 or more grains in 5 sections was judged specifically labeled. were interposed, i.e., each $b_{1}$ contacted a separate domain of the alpha cell dendrite. Thus, the observations made on the restriction of an individual $b_{1}$ 's contacts to one side of a branch point, and on exclusive territories for each $b_{1}$, seem to be a general feature of $\mathrm{ON}$-alpha cells.

Inputs from other cone bipolar, rod bipolar, and amacrine cells. Dark cone bipolars contributed only 5 contacts in strata 3 and 4 and thus were a minor input, as they were for cell 1 (Fig. 13, $E, F)$. We did not find any type $\mathrm{b}_{5}$ varicosities contacting cell 2; all presynaptic dark bipolar processes were either of fine or moderate diameter. Some dark cone bipolar contacts at the border of strata 4 and 5 , however, may have been from processes that interconnected type $b_{5}$ varicosities. Three rod bipolar cells contributed one contact each. These were restricted to strata 3 and 4 , and were thus restricted to the periphery of the dendritic field, just as for cell 1. Amacrine cells contributed the majority of synapses (436); these were concentrated in strata 3 and 4 , with fewer in stratum 5 , and were distributed throughout the dendritic field (Fig. 13, $G, H$ ). Amacrines in this series of sections could not be distinguished by their ability to accumulate ${ }^{3} \mathrm{H}$ glycine because autoradiography was not performed. In summary, the proportion of all bipolar contacts contributed by each bipolar type was similar for both cells 1 and 2 (Table 2). The proportion of bipolar and amacrine inputs could not be compared for the 2 cells because, as already discussed, our ability to locate amacrine synapses on the alpha cell 1 may have been limited by dark staining. Contacts from each neuronal type or class also had similar laminar and tangential distribution for both alpha cells.

\section{Discussion}

\section{Input from identified types}

We have identified several of the specific neuronal types that contribute input to the $\mathrm{ON}$-alpha cell by partially reconstructing its dendritic tree and tracing the synapses upon it back to their cells of origin. Cell 1 was studied most completely ( $40 \%$ of its dendritic field, covering one full diameter) and cell 2 somewhat less so (about $20 \%$ of its dendritic field, covering a full radius). The input to these 2 cells from each identified type was similar in proportion and distribution. These results allow the following extrapolations from cell 1 to an entire alpha cell: An ON-alpha cell in the area centralis receives about 1950 chemical synapses. No evidence was found for electrical synapses, despite the suggestion from physiology that they exist (Mastronarde, 1983). About 450 synapses are from cone bipolar $b_{1}$, and this represents the convergence of about 150 individual $b_{1}$ axons, each of which contributes an average of 3 contacts. About 13 synapses are from cone bipolar $b_{5}$ (number of individual cells unknown). About 28 synapses are from rod bipolar cells, each contact from a different individual cell. About 60 additional synapses are from dark cone bipolars and derive from cone bipolars $b_{2}-b_{4}$ in some unknown proportion. About 1400 contacts derive from amacrine cells (adjusted for overlooked conventional synapses; see Alpha cell 1, Synaptic contact, above) whose types remain uncertain; however, about 270 of these contacts are from glycine-accumulating processes, and these probably belong to type A4, since that type is known to accumulate glycine, to ramify in stratum 3, and to contact ganglion cells (Kolb et al., 1981; Kolb and Nelson, 1984; Pourcho and Goebel, 1985). 

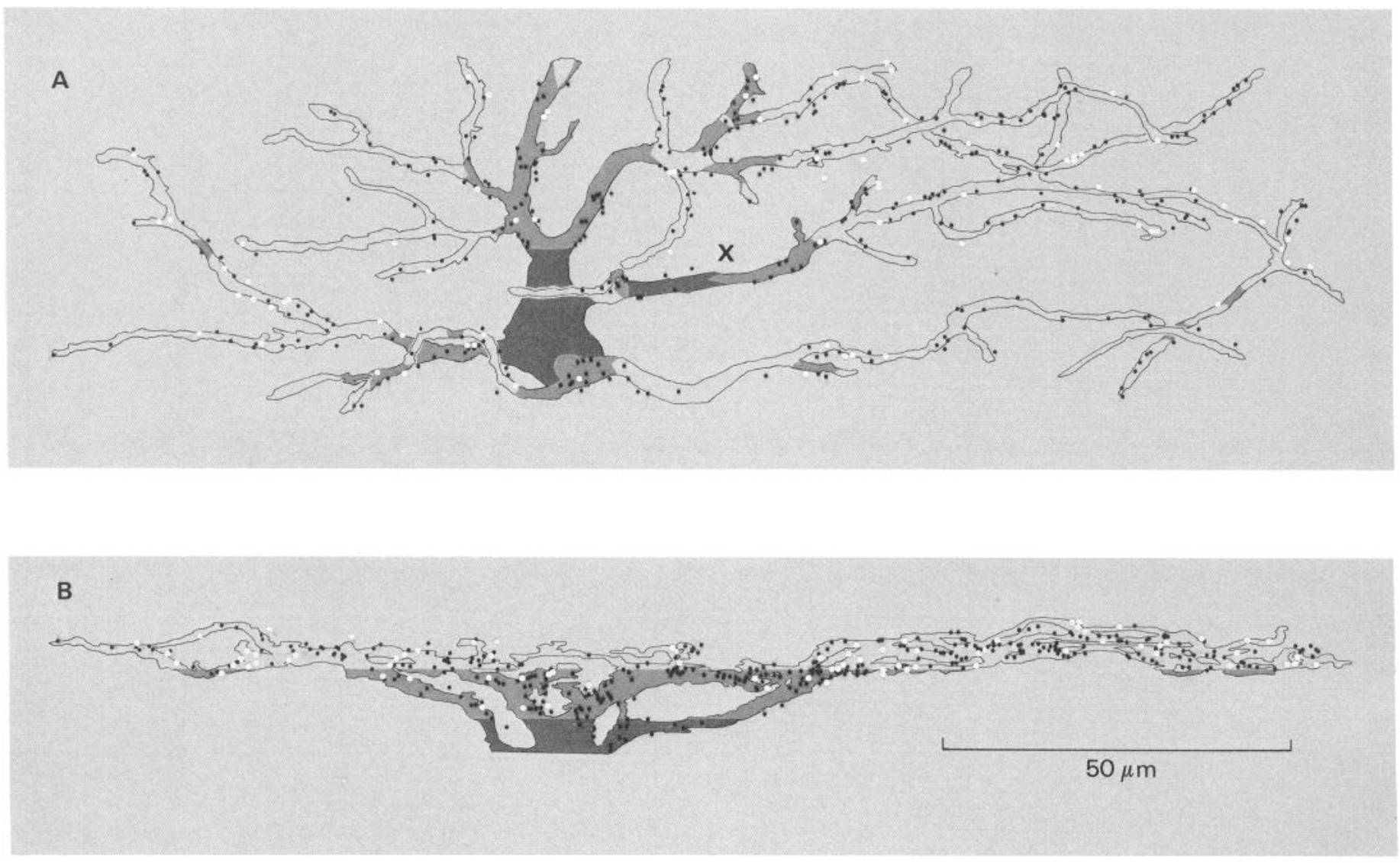

Figure 12. Distribution of contacts from glycine-accumulating amacrines (white dots) and non-glycine-accumulating amacrines (black dots) on alpha cell 1 . $A$, Tangential view. $B$, Radial view. Most amacrine contacts lie in strata 3 and 4, but some non-glycine-accumulating amacrine contacts lie in stratum 5.

\section{Global patterns of contact}

Affinity of type $b_{1}$ and rod bipolar for alpha cell. The $\mathrm{ON}$-alpha cell receives synaptic contacts from about $84 \%$ of $b_{1}$ bipolars whose axon stalks penetrate the planar $\mathrm{ON}$-alpha dendritic tree. This in turn implies that each $b_{1}$ axon stalk contacts about $84 \%$ of ON-alpha arbors that overlie the retinal position of its axon stalk. This can be verified: each point on the retinal surface is covered by about $1.4 \mathrm{ON}$-alpha cells (Wässle et al., 1981), which implies that each $b_{1}$ contacts $1.2 \mathrm{ON}$-alpha cells: this is identical to the number calculated in Results by other means.
The few $b_{1}$ axon stalks within the dendritic field that fail to provide synaptic contacts are located more than $5 \mu \mathrm{m}$ from the nearest alpha dendrite. Similarly, stalks that lie beyond the margin of the dendritic field do not provide contacts, even though their axon arbors overlap it. These observations suggest that in the development of the wiring between these 2 cell types there is some kind of interaction between the $b_{1}$ axon stalk and the alpha dendrite that leads reliably to the formation of synaptic contacts but that operates over a rather short distance. Thus, the dendrite and stalk must be brought together in order that the axon termination can form synapses. Indeed, there is an

Table 2. Proportion of synaptic contacts from $\mathrm{CBb}_{1}$ cone bipolar $\left(\mathrm{b}_{1}\right)$, dark cone bipolar $(\mathrm{dbp})$, rod bipolar cells (RB), and amacrines cells on partial reconstructions of 2 alpha cells in sublamina $b$ of the retina

\begin{tabular}{|c|c|c|c|c|c|}
\hline & $\mathrm{b}_{1}$ & $\mathrm{dbp}$ & RB & Amacrine & \\
\hline ON-alpha 1 no. of synapses & 179 & 29 & 11 & 439 & Glycine: 83 \\
\hline Bipolar \% & 82 & 13 & 5 & & Non-glycine: 356 \\
\hline Total $\%$ & & 33 & & 67 & \\
\hline ON-alpha 2 no. of synapses & 63 & 5 & 3 & 436 & \\
\hline Bipolar \% & 89 & 7 & 4 & & \\
\hline Total (\%) & & 14 & & 86 & \\
\hline
\end{tabular}

List of the percentages of bipolar input (bipolar \%) each bipolar class contributes, and, in addition, the percentage of total input, bipolar and amacrine that each neuronal class contributes. 
A

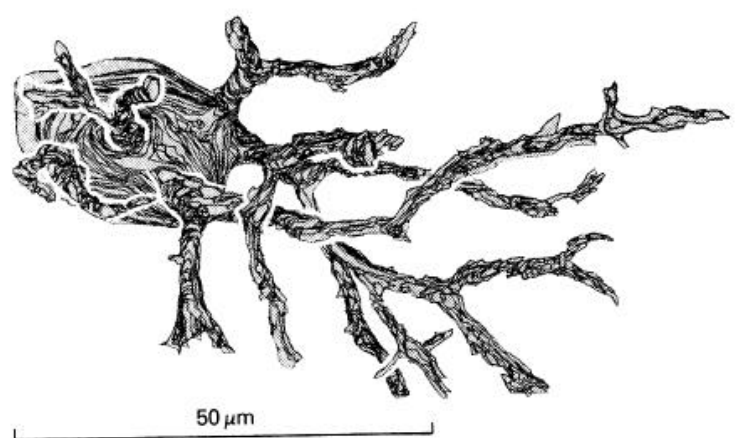

B
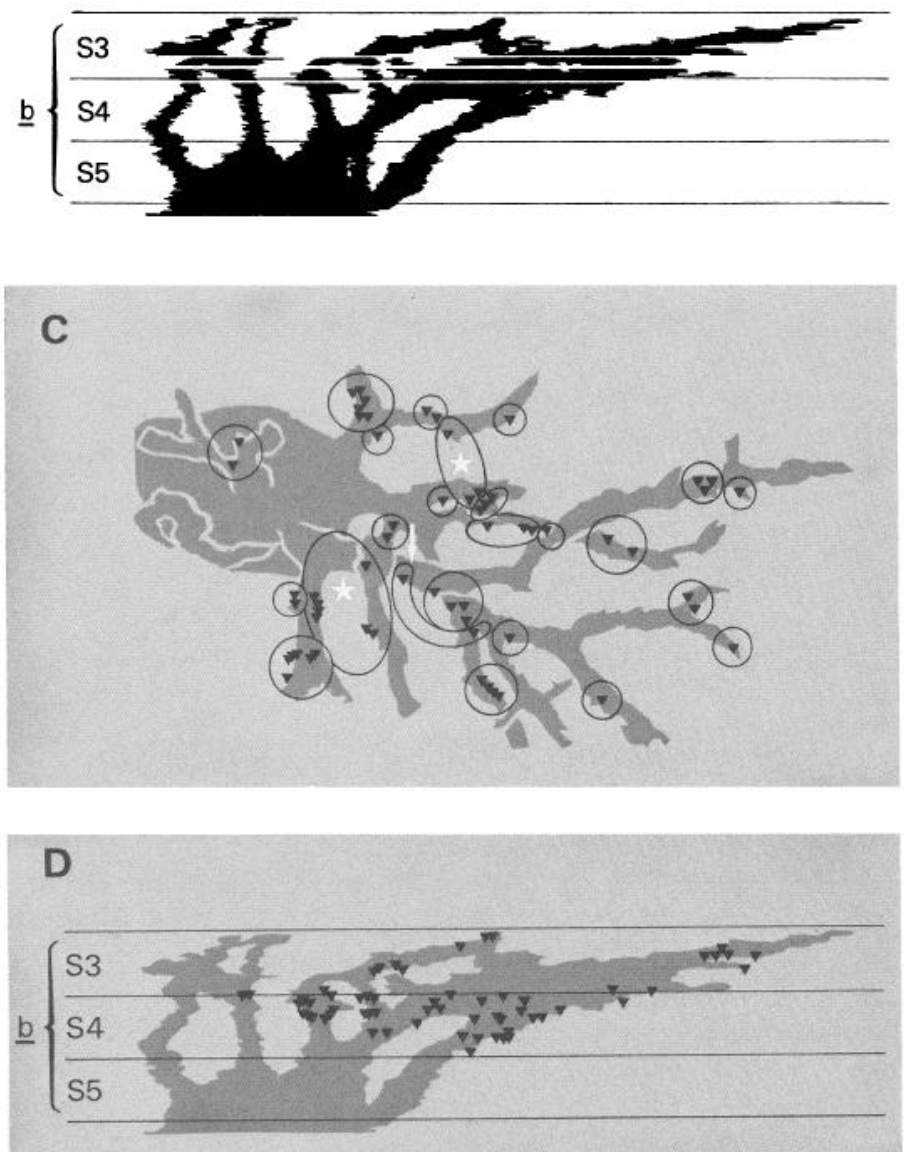

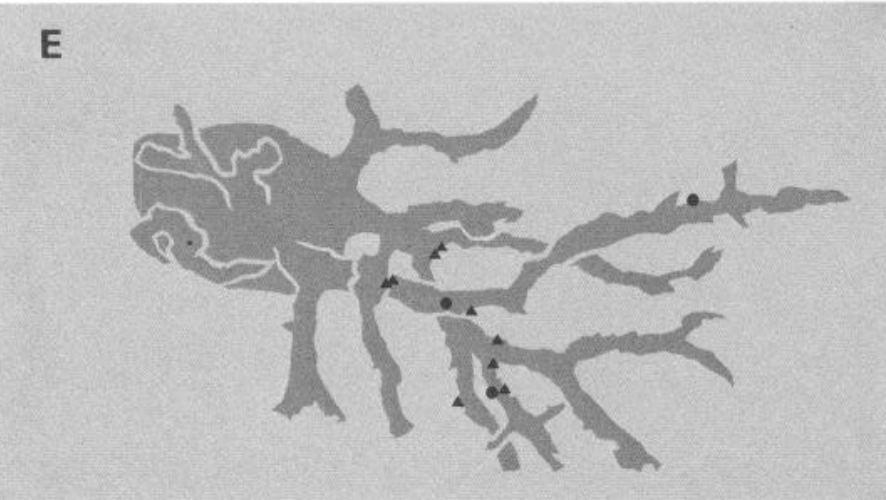

F

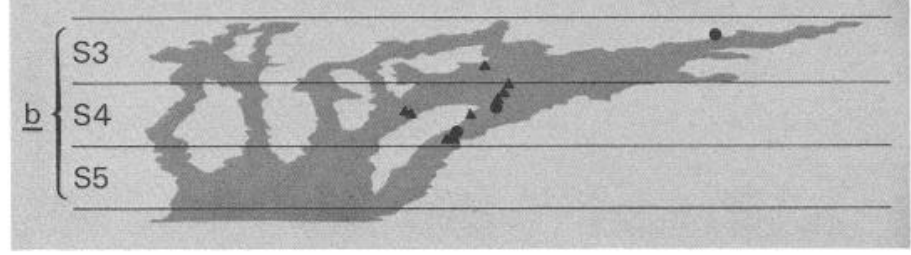

G

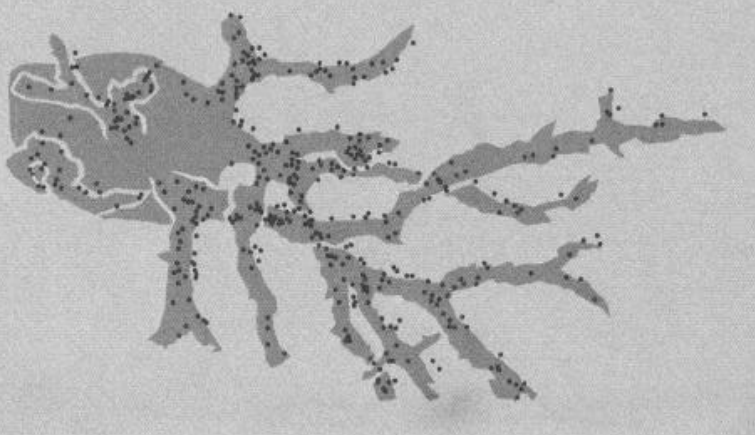

H

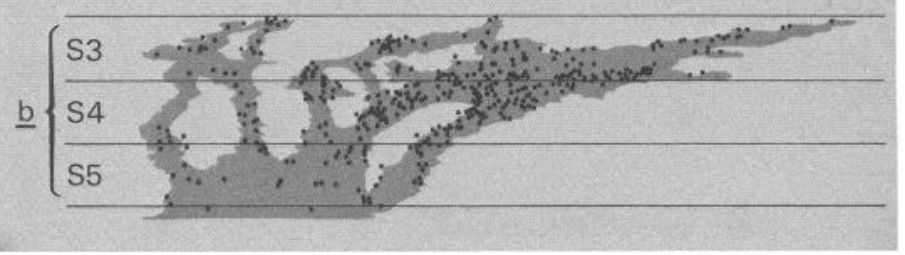

Figure 13. The distribution of synapses on a partial reconstruction of alpha cell 2. All symbols have the same meaning as in previous figures. A, Tangential view of reconstructed dendrites. $B$, Radial view of reconstructed dendrites; horizontal breaks are due to missing sections. $C, D$, Distribution of contacts from type $b_{1}$ cone bipolars (triangles). Each encircled group of triangles indicates synapses from an individual $b_{1}$ axon. All contacts from a single $b_{1}$ were on the distal side of a branch point, with one exception (arrow). Synapses from the same $b_{1}$ were usually on dendrites originating from the same parent branch with 2 exceptions (*). E, F, Distribution of contacts from dark cone bipolars (triangles) and rod bipolars (circles). $G$, $H$, Distribution of contacts from amacrine cells $($ dots $)$.

apparent correspondence between the position of the presynaptic $b_{1}$ axon stalks and the course of the alpha dendrites (see Fig. 5). One could not guess a priori whether the pre- and postsynaptic elements are brought together by growth of the dendrites toward the axon or vice versa; however, it is known that the full branching pattern of the alpha cell is established by birth
(Ramon y Cajal, 1929; Maslim et al., 1986), well before the cone bipolar axon stalks have descended into the inner plexiform layer (Ramon y Cajal, 1929; P. Sterling, unpublished observations). This seems to suggest that the stimulus for connection emanates from dendrites and attracts the ingrowing axons. This is not the only possibility, since the dendrites at this stage 
A

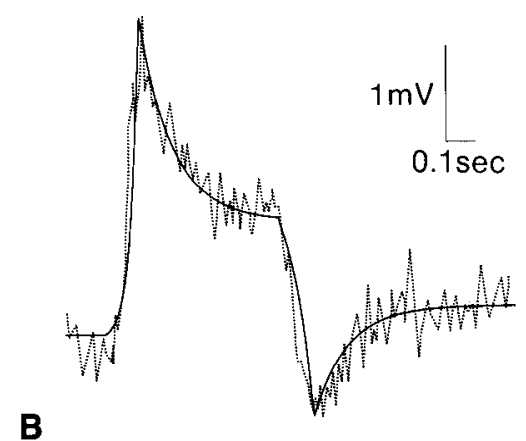

B

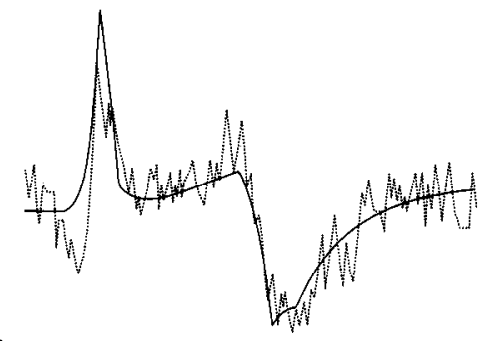

C

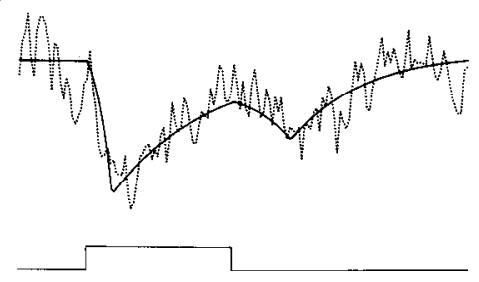

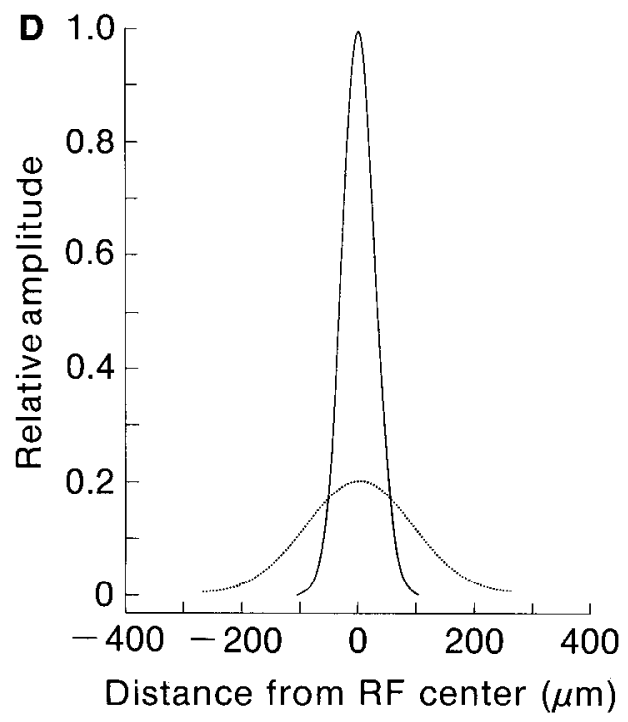

Figure 14. A, Dotted trace, response recorded intracellularly from a type $\mathrm{b}_{1}$ to stimulation of the receptive-field center (Nelson and Kolb, 1983). Note moderately transient depolarization to stimulus onset and hyperpolarization to stimulus offset (full-wave rectifying). $B$, Dotted trace represents recorded response to stimulation of both center and surround. $C$, Dotted trace represents pure surround response derived by subtracting center response $(A)$ from center + surround response $(B)$. Before subtraction, center response was scaled to have the same transient amplitude as that of the mixed response. Note that the derived response for the surround is hyperpolarizing to both onset and offset of the stimulus (half-wave rectifying) and that the response to stimulus onset is delayed with respect to the center response. Such a pure surround response has been recorded from another $\mathbf{b}_{1}$ (Nelson et al., 1981, their figure 3). This procedure for deriving the surround response was checked by fitting both the recorded center response and the derived surround response with a series of exponential equations (solid line, $A$ and $C$ ). When these fitted responses were added, they gave the solid line in $B$, which was a good fit to the mixed response. $D$, Gaussian distribution over space of the $b_{1}$ center response (solid line) and the $b_{1}$ surround response (dotted line). The smallest center space constants measured for the $b_{1}$ bipolar are about $40 \mu \mathrm{m}$; the surround space constant has been measured at $130 \mu \mathrm{m}$ (Nelson et al., 1981; Nelson and Kolb, 1983). These last 2 values were substituted for the roughly equivalent parameter $r$, which describes the width of a Gaussian distribution at 1/e of its peak amplitude value.

are still undergoing interstitial growth (Maslim et al., 1986) and may be capable of local readjustment of their positions.

Only about $3 \%$ of rod bipolars within the ON-alpha dendritic field contact it, far fewer than the proportion of presynaptic axons within the $b_{1}$ array. The rod bipolar array is much denser than the $b_{1}$ array; therefore, many more rod bipolar axon stalks that $b_{1}$ axon stalks come close to an ON-alpha dendrite. Thus the lack of numerous connections between the rod bipolar array and the alpha dendrites is not due to a failure of the 2 types to be in proximity but apparently to a relatively low affinity of the rod bipolar cell for forming contacts on the ON-alpha cell.

Concentric synaptic patterns on the alpha cell. Contacts on the alpha cell from specific types of presynaptic neuron distribute concentrically. There are 2 apparent causes for this concentric distribution. (1) The concentric distribution of input from certain types appears to stem from the stratification of their presynaptic arbors: the $b_{5}$ bipolar's arbor is restricted to stratum 5; thus its synapses onto the ON-alpha cell are restricted to the junction of strata 4 and 5 . This in turn restricts $b_{5}$ contacts to the center of the alpha dendritic field, which lies at this level.
The A4 has an arbor limited to strata 2 and 3 (Kolb, 1984), which would concentrate its contacts onto the alpha cell in stratum 3, where the peripheral portions of the alpha dendritic tree ramify. (2) The stratification of input from other types, and the corresponding annular distribution of this input occurs despite the broader, more diffuse stratification of the presynaptic arbor: the rod bipolar forms contacts with various neurons in all strata of sublamina $b$. Yet the contacts from the rod bipolar cell onto the alpha cell are concentrated in stratum 3, with few contacts in stratum 4 , and thus are restricted to the more distal alpha dendrites that lie at this level. The $b_{1}$ contacts various neurons, particularly the ON-beta cell, in all strata of sublamina $b$. Yet the $b_{1}$ bipolar does not contact the ON-alpha cell in stratum 5 . It avoids a small area at the center of the dendritic arbor, which lies in stratum 5, but contacts throughout the rest of the dendritic arbor, which lies in strata 3 and 4 . It should be noted, for all of these cases, however, that there is, at present, no way of determining whether the stratified distribution of contacts causes their concentric distribution in the alpha dendritic tree or vice versa. 
A

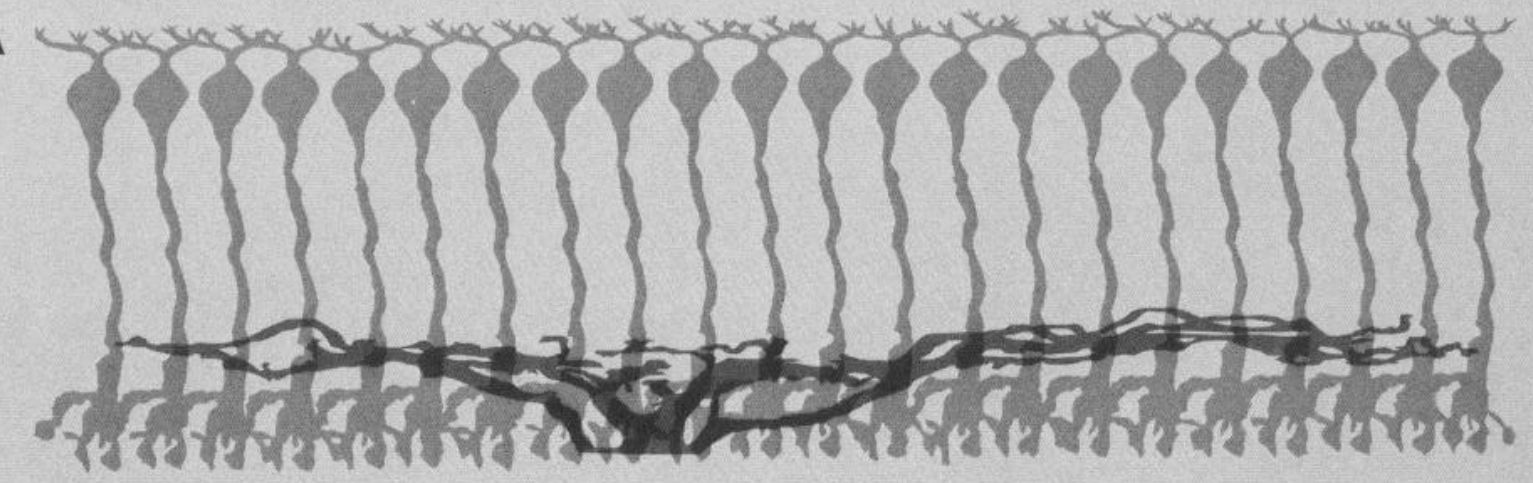

B
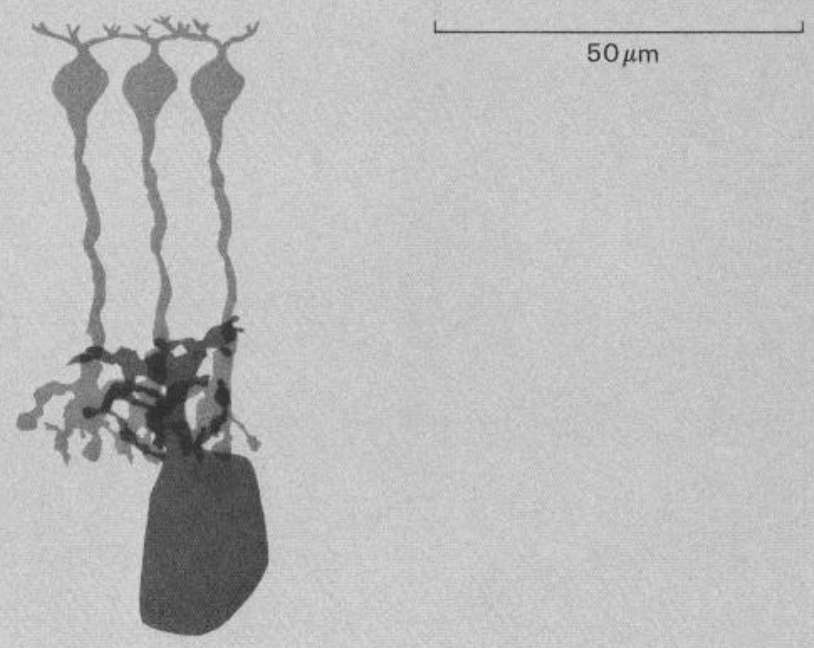

Figure 15. A, ON-alpha dendritic tree in radial view. Twenty-two $\mathrm{b}_{1} \mathrm{~s}$ provide input across the full diameter of the dendritic field. $B$, ON-beta cell in radial view. Three $b_{1} s$ provide input across one full diameter of the dendritic field.

\section{Local patterns of contact}

The positions of contacts from individual neurons on the ONalpha arbor appear to follow at least 5 local rules: (1) Contacts from an individual bipolar cell cluster on the $\mathrm{ON}$-alpha dendrites and do not intermingle with the clustered contacts from other bipolars; (2) amacrine contacts do intermingle with the clusters of contacts from a single bipolar; (3) bipolar axons (but not amacrine processes) contact dendritic thorns on the alpha cell; $b_{1}$ axons (but not other bipolar cells) are invaginated by these thorns; (4) an individual $b_{1}$ axon almost always contacts daughter branches from the same parent dendrite; (5) contacts from an individual $b_{1}$ are almost always $(82 / 86)$ restricted to one side of a branch point (see Figs. $6 A, 13 C$ ).

The developmental mechanism required to establish rule 5 in the adult is unclear. It cannot, however, be trivial. In stratum 3 , the restriction of contacts from an individual $b_{1}$ to one side of an alpha branch point could stem from the limited potential for contact between these 2 types, because, in that stratum, the $b_{1}$ contacts arise from the axon stalk, which has a narrow tangential spread ( $3 \mu \mathrm{m}$ diameter). Within stratum 4 , however, a $b_{1}$ contacts to the alpha cell arise from the whole axonal arbor (as evidenced by distances between contacts from the same bi- polar of as much as $10 \mu \mathrm{m}$; Fig. $3 A$ ), and thus there is ample potential for the $b_{1}$ axon to contact both sides of a branch point. Yet there was no instance in stratum 4 of contacts from an individual $b_{1}$ straying across a branch point. Thus, in stratum 4 , the restriction of $b_{1}$ contacts to a single side of a branch point cannot be the trivial result of a limited geometric potential for contact. Instead, since, as noted, the branch points exist prior to the growth of the $b_{1}$ axon and the formation of contacts, the $b_{1}$ axon must be able to recognize branch point already formed. Antigens in the alpha cell postsynaptic to specific types of presynaptic neuron have been identified immunocytochemically (Sterling and Lampson, 1986). It is possible that such molecules mark specific sites on a cell, such as the loci distal to a branch point, as targets for a specific type of presynaptic input.

\section{Contribution of the type $b_{1}$ bipolar array to ganglion cell receptive fields}

One purpose of this investigation was to discover the anatomical basis of the ganglion cell's receptive field by identifying the anatomical circuits to the alpha ganglion cell from specific cell types. The most detailed anatomical data was obtained for the $b_{1}$ circuit to the $\mathrm{ON}$-alpha cell. This was fortunate because the $\mathrm{b}_{1}$ is the dominant bipolar input to the ON-alpha cell and its 

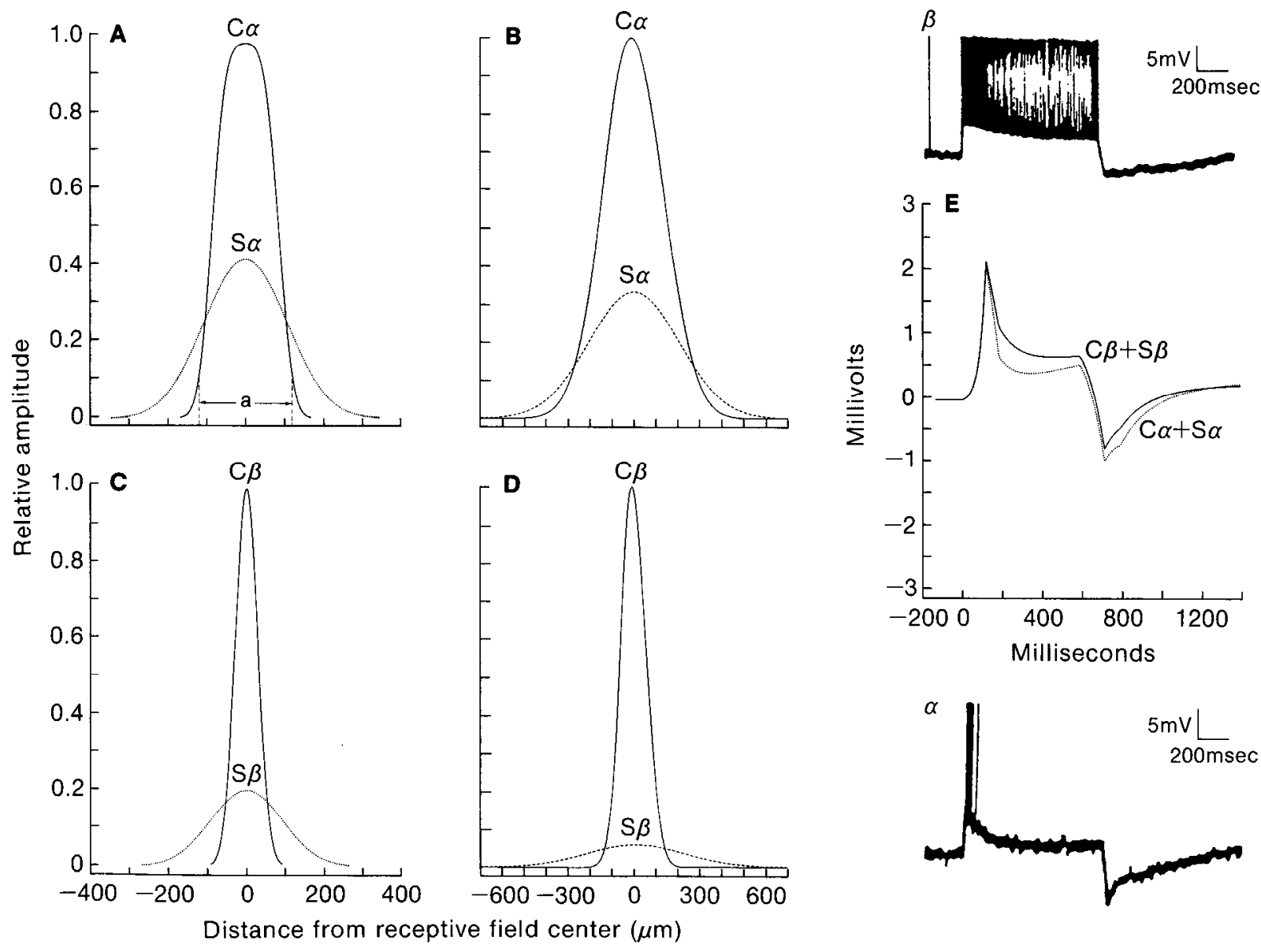

Figure 16. A, Contribution of $22 \mathrm{~b}_{1}$ centers $(C \alpha)$ and surrounds $(S \alpha)$ to the $\mathrm{ON}$-alpha cell. Curves obtained by algebraically summing the Gaussian distributions of $b_{1}$ center or surround response amplitudes across space. Note that the combination of centers has widened more than the combination of surrounds, and the combination of surrounds has increased in amplitude at the center. The diameter of the combined $b_{1}$ centers at $10 \%$ of its peak height $(b)$ is $250 \mu \mathrm{m}(a)$; this matches the measurement of $O N$-alpha center size by Peichl and Wässle (1983). $B$, Average center and surround Gaussian sensitivity distribution of alpha cells (both ON and OFF) throughout the retina. Note that the actual receptive-field structure is similar to the predicted $\mathrm{b}_{1}$ contribution in part $A$. $C$, Proposed contribution of $3 \mathrm{~b}_{1}$ centers $(C \beta)$ and surrounds $(S \beta)$ to the ON-beta cell. Curves obtained as in $A$. The original relationship between the width and the amplitude of the $\mathrm{b}_{1}$ center and surround is retained. $D$, Average center and surround Gaussian sensitivity distribution of beta cells (both ON and OFF) throughout the retina (taken from Linsenmeier et al., 1982). Note that the surround is broad compared to the center and thus there is less center-surround overlap than for the alpha cell, as predicted from the $b_{1}$ contribution in $B$. $E$, Modeled time course of $b_{1}$ contribution to alpha and beta cells compared to intracellular recordings. The net $b_{1}$ response caused by stimulation at the middle of alpha and beta receptive-field centers was modeled by using the peak amplitudes of combined $b_{1}$ centers and surrounds for alpha and beta cells $(A, B)$ to scale the $\mathrm{b}_{1}$ center and surround responses (see Fig. 15, $A, C$, solid lines). These scaled responses were then summed to give the time course of the net $b_{1}$ contribution. The $b_{1}$ contribution to the alpha cell receptive field (lower, dotted line) is more transient than the contribution to the beta cell receptive field (upper, solid line). Above and below the predicted responses are intracellular recordings from ON-beta $(\beta)$ and $\mathrm{ON}$-alpha $(\alpha)$ cells that show this same transient-sustained distinction. For both intracellular traces: white light stimulus, stimulus intensity approximately $-3 \log \mathrm{W} / \mathrm{cm}^{2}$; background approximately $-4 \log \mathrm{W} / \mathrm{cm}^{2}$ (from Saito, 1983).

physiological response and receptive-field structure have been characterized (Nelson et al., 1981; Nelson and Kolb, 1983). The $b_{1}$ itself has a center-surround receptive field with a moderately transient, depolarizing center and a hyperpolarizing surround. Stimulation of the center and surround simultaneously causes a sharply transient response (see Fig. 14, $A-C$ ).

To study the possible contribution of the $b_{1}$ array to the ONalpha cell, we represented the $b_{1}$ receptive field by 2 Gaussians distributions, one for the receptive-field center, one for the surround. These distributions were derived from empirical measures (see Fig. 14D). We approximated a "net receptive field" for the $b_{1}$ array presynaptic to the alpha cell. This approximation was one-dimensional, a summation of the receptive fields of the $22 b_{1}$ s across the diameter of the array (Fig. 15). The center and surrounds were summed separately. For purposes of compari- son, the receptive fields of the $3 b_{1} s$ across the diameter of the array presynaptic to the beta cell were also summed.

The net receptive field of the $b_{1}$ array presynaptic to the ONalpha cell had a broad center and a surround of high amplitude (Fig. 16A). The surround was nearly coextensive with the center. These features of the net receptive field for the $b_{1}$ array resemble the receptive field of the alpha cell itself (Cleland and Levick, 1974; Linsenmeier et al., 1982; Peichl and Wässle, 1983) (Fig. $16 B$ ). Illumination at the center of the net receptive field of the $b_{1}$ array stimulates $b_{1}$ centers and surrounds simultaneously, thus producing a net response that is a mixture of $b_{1}$ center and surround responses. At this position, the surround of the net $b_{1}$ receptive field is of high amplitude and overlaps the center. This suggests that since the simultaneous stimulation of center and surround evokes a transient response from the $b_{1}$ bipolar, the 

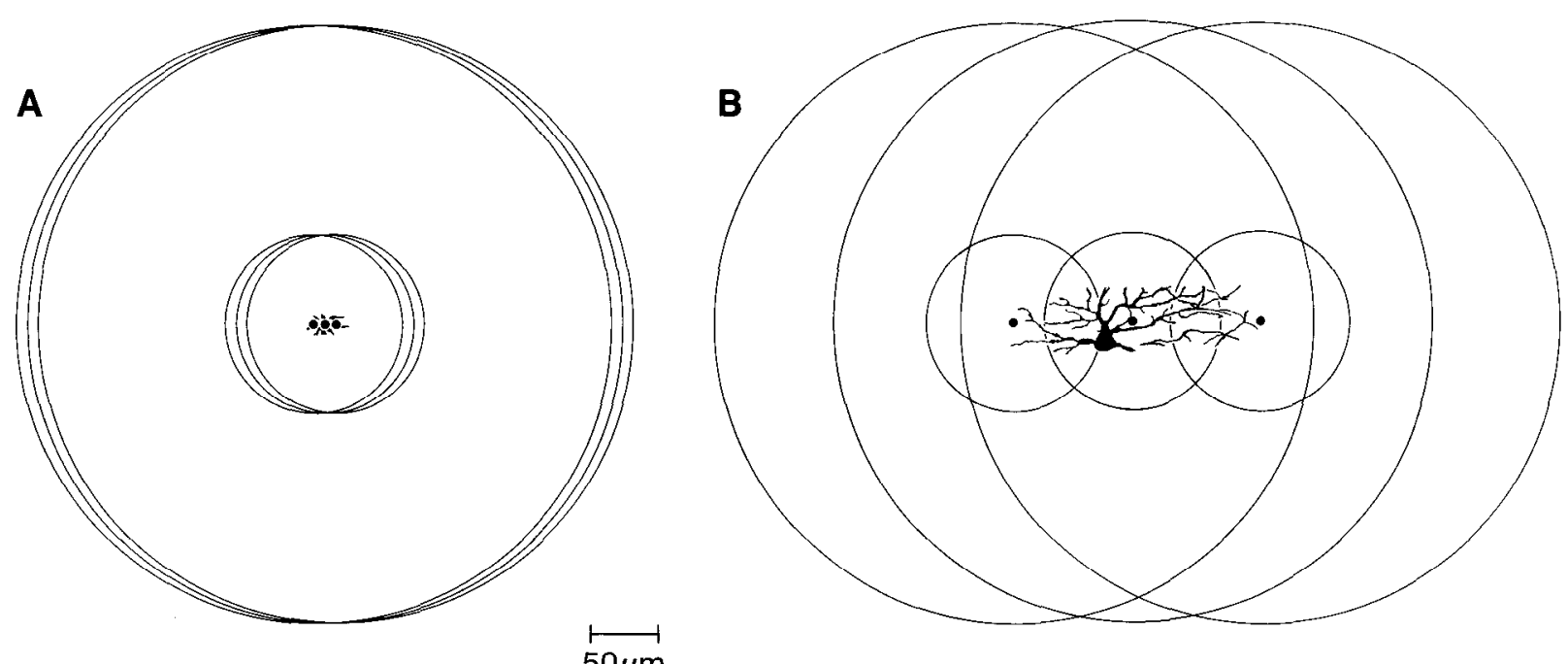

$50 \mu \mathrm{m}$

Figure 17. Model of the $\mathrm{b}_{1}$ contributions to ON-beta and ON-alpha ganglion cells. $A$, ON-beta cell. Dots represent the 3 members of the $\mathrm{b}_{1}$ array that contact the beta cell arborization across its diameter. The small circles represent bipolar receptive-field centers, and the large circles the receptive-field surrounds (circle radius is twice the space constant; see legend to Fig. 15.). Because the spacing of the bipolars is close compared to their receptive-field sizes, the bipolar receptive fields are essentially in register. Stimulation at any point in the middle of the beta receptive field causes stimulation of the same number of $b_{1}$ surrounds as centers; thus, the original center-surround balance in the $b_{1}$ is preserved. $B$, ON-alpha cell. Dots represent 3 of the 22 members of the $b_{1}$ array that contact the alpha cell arborization across its diameter. Because the array is large compared to the bipolar receptive-field size, the receptive fields are not concentric. Stimulation of any point in the middle of alpha cell receptivefield stimulates more $b_{1}$ surrounds than centers; although both surrounds and centers have the same spacing, the surrounds are bigger and thus have a greater coverage factor. This changes the center-surround balance of the $b_{1}$ contribution to favor the surround. Upon stimulation in the middle of either ganglion cell's receptive field, the greater admixture of $b_{1}$ surround for the alpha cell would cause the $b_{1}$ contribution to the alpha cell to be more transient than the $b_{1}$ contribution to the beta cell.

transient response from the alpha cell center arises from a mixture of $b_{1}$ centers and surrounds (Fig. 16E).

The net receptive field of the $b_{1}$ array presynaptic to the ONbeta cell has a relatively narrow center and broad surround (Fig. $16 C$ ) that closely resembles the original receptive field structure of the $b_{1}$ bipolar. These features of the net receptive field of the $b_{1}$ array presynaptic to the beta cell also resemble the beta receptive field (Fig. 16D). Illumination at the center of the net receptive field of the $b_{1}$ array causes a moderately transient response, since there is only a small admixture of $b_{1}$ surround responses in the center of the array (Figs. 16E, 17).

Thus the net receptive field of the $b_{1}$ array presynaptic to either ganglion cell resembles the ganglion cell receptive field itself. Moreover, the net receptive field of the $b_{1}$ array presynaptic to the beta cell is moderately transient, but the net receptive field of the $b_{1}$ array presynaptic to the alpha cell is sharply

Table 3. Comparison of the measured and predicted ganglion cell receptive-field center and surrounds in the area centralis

\begin{tabular}{llllll} 
& \multicolumn{2}{l}{ Alpha cell } & & Beta cell & \\
\cline { 2 - 3 } & Center & $\begin{array}{l}\text { Sur- } \\
\text { round }\end{array}$ & & Center & $\begin{array}{l}\text { Sur- } \\
\text { round }\end{array}$ \\
\hline$r$ Measured (deg) & 0.5 & 0.9 & & 0.2 & 0.7 \\
$R$ (deg) & 0.54 & - & & $0.15-0.2$ & - \\
$r$ Predicted (deg) & 0.5 & 0.7 & & 0.2 & 0.6
\end{tabular}

The parameter $r$ Measured, which is the radius of a Gaussian distribution at $1 / e$ of the peak amplitude value, is the smallest measured by Linsenmeier et al. (1982, and personal communication). $R$ is a roughly equivalent measure, derived from measurements of ganglion cell threshold as a function of the area of test stimuli (Cleland and Levick, 1974; Peichl and Wässle, 1979). $r$ Predicted is the width of the $b_{1}$ contribution to the center or surround at $l / e$ of its peak amplitude value (see text). transient. It has been found empirically that the alpha cell responds to stimulation at its receptive-field center with a sharper transient than that of the beta cell when both are recorded in the same region of retina, under the same state of adaptation, and for the same intensity of stimulus (Cleland et al., 1973; Jakiela and Enroth-Cugell, 1976).

Linearity and nonlinearity. As a contrast-reversing periodic stimulus is moved across the net receptive field of the $b_{1}$ array presynaptic to the alpha cell, this array responds at all positions. Thus, this net receptive field lacks a "null position." This is because the $b_{1}$ center response to the dark and light bars of such a stimulus are of opposite polarity and would tend to cancel, but the $b_{1}$ surround response to dark and light bars are of the same polarity and would not cancel. Thus there would be a net response at twice the temporal frequency of reversal (second harmonic). The time course of the net $b_{1}$ response would depend on the spatial frequency of the periodic reversing stimulus. A stimulus of low enough frequency such that one bar covers all of the $b_{1}$ centers in the array simultaneously would cause them to respond in synchrony, producing a large response at the fundamental temporal frequency of reversal. A stimulus of higher spatial frequency, such that small dark and light bars just cover individual $b_{1}$ surrounds, would produce the greatest response at the second harmonic. Thus, the net responses to periodic stimuli found for the alpha cell's presynaptic $b_{1}$ array shows 3 features: (1) no null position, (2) low spatial frequencies optimal for eliciting a linear response at the fundamental temporal frequency, and 3) high spatial frequencies optimal for a nonlinear response at the second harmonic. All these features have been noted for the alpha cell itself (Enroth-Cugell and Robson, 1966; Hochstein and Shapley, 1978a, b).

The spatial frequency sensitivity of the fundamental linear response in the alpha cell led Hochstein and Shapley (1976a, b) 
to suggest that this response comes from the linear alpha receptive-field center. In suggesting that an array of $b_{1}$ centers contributes to this larger alpha receptive-field center, our observations imply that the alpha receptive-field center is a linear summation of an array of smaller linear units. The spatial frequency selectivity of the alpha center is determined by the size of the array as a whole, not by the spatial frequency selectivity of the constitutive units. The response at the second harmonic led Hochstein and Shapley (1976b) to suggest that the alpha cell receives input from an array of nonlinear subunits throughout its receptive field. The present observations suggest that these subunits may correspond to individual $b_{1}$ surrounds. If so, the nonlinearity present in the alpha cell derives from a linear summation of nonlinear inputs. The beta cell receptive-field center does not show as much nonlinearity; this may reflect the smaller contribution of the $b_{1}$ surround to the beta cell response to stimulation at the center of the receptive field.

It is encouraging that, when the responses of the $b_{1}$ cells in the circuit to alpha and beta cells are summed linearly in space and time, the results are congruent with actual properties of the ganglion cell receptive-fields (see Table 3 ). Yet this result cannot completely account for the receptive fields, because many factors intervene between the depolarization of the $b_{1}$ axon and the firing of a ganglion cell. For a full account, one needs to know the transfer function for the $b_{1}$ synapses upon the ganglion cells and the electrotonic losses in the ganglion cell dendritic tree (which would cause $b_{1} s$ at different distances from the alpha cell body to have different weights). A complete account would also need to include the contributions of the full 2-dimensional array ( $150 b_{1}$ bipolars), as opposed to the purely one-dimensional case presented here. That the summed responses in the one-dimensional calculation are close to the actual ganglion cell receptive-field properties may suggest that these factors, as yet unmeasured, are relatively minor determinants compared to the receptive-field structures of the $b_{1}$ and the structures of the arrays presynaptic to the ganglion cells.

In one major respect the alpha and beta cells' responses are quite different from the combined responses of their $b_{1}$ inputs. A light turned off in the ganglion cell's receptive-field surround depolarizes these cells, but a light turned off in the surround of the $b_{1}$ receptive field causes the opposite response, a hyperpolarization. This implies that some input to the ganglion cells other than the $b_{1}$ must account for the surround off-responses, perhaps by antagonizing the nonlinear behavior of the $b_{1}$ surround. This reminds one that about $80 \%$ of the input to the alpha cell and about $50 \%$ to the beta cell (see Table 2) are from amacrines whose types and responses are still unidentified. Therein lies the next major challenge in investigating the anatomical basis of ganglion cell function.

Note added in proof: It has come to our attention that a model of the Y/alpha receptive field structure, based on extracellular electrophysiology, has been published by Enroth-Cugell and Freeman (1987). This model includes an array of overlapping subunits with center-surround structure which we would suggest corresponds to the receptive fields of presynaptic cells, including the $\mathrm{b}_{1}$ bipolar.

\section{References}

Adams, J. C. (1977) Technical considerations on the use of horseradish peroxidase as a neuronal marker. Neuroscience 2: 141-145.

Boycott, B. B., and H. Wässle (1974) The morphological types of ganglion cells of the domestic cats retina. J. Physiol. (Lond.) 240: $397-419$.
Cleland, B. G., and W. R. Levick (1974) Brisk and sluggish concentrically organized ganglion cells in the cats retina. J. Physiol. (Lond.) 240: $421-456$.

Cleland, B. G., W. R. Levick, and K. J. Sanderson (1973) Properties of sustained and transient ganglion cclls in the cat retina. J. Physiol. (Lond.) 228: 649-680.

Cohen, E., and P. Sterling (1986) Accumulation of $\left({ }^{3} \mathrm{H}\right)$ glycine by cone bipolar neurons in the cat retina. J. Comp. Neurol. 250:1-7.

Cohen, E., and P. Sterling (1987) The mosaic of cone bipolar neurons innervating the on-sublamina of the cat retina inner plexiform layer. Invest. Ophthalmol. Vision Sci. (Suppl.) 28: 403.

Davis, T. L., R. F. Spencer, and P. Sterling (1979) Preparing autoradiograms of serial sections for electron microscopy. J. Neurosci. Methods 1: 179-183.

Dowling, J. E., and B. B. Boycott (1966) Organization of the primate retina: Electron microscopy. Proc. R. Soc. Lond. [Biol.] 166: 80-111.

Enroth-Cugell, C., and A. W. Freeman (1987) The receptive-field spatial structure of cat retinal Y cells. J. Physiol. (Lond.) 384: 49-79.

Enroth-Cugell, C., and L. H. Pinto (1972a) Properties of the surround response mechanism of cat retinal ganglion cells and centre-surround interactions. J. Physiol. (Lond.) 220: 403-439.

Enroth-Cugell, C., and L. H. Pinto (1972b) Pure central responses from off-centre cells and pure surround responses from on-centre cells. J. Physiol. (Lond.) 220: 441-464.

Enroth-Cugell, C., and J. G. Robson (1966) The contrast sensitivity of retinal ganglion cells of the cat. J. Physiol. (Lond.) 187: 517-552.

Famiglietti, E. V., Ir., and H. Kolb (1976) Structural basis for on- and off-center responses in retinal ganglion cells. Science 194: 193-195.

Freed, M. A., R. Smith, and P. Sterling (1987) The rod bipolar cell in cat retina: Pattern of input from rods and GABA-accumulating amacrine cells. J. Comp. Neurol. 266: 445-455.

Fukuda, Y., C.-F. Hsiao, M. Watanabe, and H. Ito (1984) Morphological correlates of physiologically identified $\mathrm{Y}, \mathrm{X}$ and $\mathrm{W}$ cells in the cat retina. J. Neurophysiol. 52: 999-1013.

Hickey, T. L., R. W. Winters, and J. G. Pollack (1973) Center-surround interactions in two types of on-center retinal ganglion cells in the cat. Vision Res. 13: 1511-1526.

Hochstein, S., and R. M. Shapley (1976a) Quantitative analysis of retinal ganglion cell classification. J. Physiol. (Lond.) 262: 237-264.

Hochstein, S., and R. M. Shapley (1976b) Linear and nonlinear spatial subunits in Y cat retinal ganglion cells. J. Physiol. (Lond.) 262: 265284.

Hoffmann, K.-P., and J. Stone (1971) Conduction velocity of afferents to cat visual cortex: A correlation with cortical receptive field properties. Brain. Res. 32: 640-646.

Jakiela, H. G., and C. Enroth-Cugell (1976) Adaptation and dynamics in X-cells and Y-cells of the cat retina. Exp. Brain. Res. 24: 335-342.

Koch, C., T. Poggio, and V. Torre (1982) Retinal ganglion cells: A functional interpretation of dendritic morphology. Phil. Trans. R. Soc. Lond. [Biol.] 298: 227-264.

Kolb, H. (1979) The inner plexiform layer in the retina of the cat: Electron microscopic observations. J. Neurocytol. 8: 295-329.

Kolb, H. (1984) Cone pathways in the mammalian retina. In Molecular and Cellular Basis of Visual Acuity, Springer-Verlag, New York.

Kolb, H., and R. Nelson (1984) Neural architecture of the cat retina. In Progress in Retinal Research, vol. 3, N. Osborne and J. Chader, eds., Pergamon, New York.

Kolb, H., R. Nelson, and A. Mariani (1981) Amacrine cells, bipolar cells and ganglion cells of the cat retina: A Golgi study. Vision Res. 21: 1081-1114.

Linsenmeier, R. A., L. J. Frishman, H. G. Jakiela, and C. Enroth-Cugell (1982) Receptive field properties of $X$ and $Y$ cells in the cat retina derived from contrast sensitivity measurements. Vision Res. 22: 1173 1183.

Maslim, J., M. Webster, and J. Stone (1986) Stages in the structural differentiation of retinal ganglion cells. J. Comp. Neurol. 254: 382402.

Mastronarde, D. N. (1983) Interactions between ganglion cells in cat retina. J. Neurophysiol. 49: 350-365.

McGuire, B. A., J. K. Stevens, and P. Sterling (1984) Microcircuitry of bipolars cells in the cat retina. J. Neurosci. 4: 2920-2938.

McGuire, B. A., J. K. Stevens, and P. Sterling (1986) Microcircuitry of beta ganglion cells in cat retina. J. Neuroscience 6: 907-918.

Mullikin, W. H., J. P. Jones, and L. A. Palmer (1984) Receptive-field properties and laminar distribution of X-like and Y-like simple cells in cat area 17. J. Neurophysiol. 52: 350-371. 
Nelson, R., and H. Kolb (1983) Synaptic patterns and response properties of bipolar and ganglion cells in the cat retina. Vision Res. 10: 1183-1195.

Nelson, R., H. Kolb, M. M. Robinson, and A. P. Mariani (1981) Neural circuitry of the cat retina: Cone pathways to ganglion cells. Vison Res. 21: 1527-1536.

Peichl, L., and H. Wässle (1979) Size, scatter and coverage of ganglion cell receptive field centres in the cat retina. J. Physiol. (Lond.) 291: 117-141.

Peich1, L., and H. Wässle (1981) Morphological identification of onand off-center brisk transient $(\mathrm{Y})$ cells in the cat retina. Proc. R. Soc. Lond. [Biol.] 212: 139-156.

Peichl, L., and H. Wässle (1983) The structural correlate of the rcceptive field center of (alpha) ganglion cells in the cat retina. J. Physiol. (Lond.) 341: 309-324.

Pourcho, R. G., and D. J. Goebel (1985) A combined Golgi and autoradiographic study of $(3 \mathrm{H})$ glycine-accumulating amacrine cells in the cat retina. J. Comp. Neurol. 233: 473-480.

Rall, W. (1959) Branching dendritic trees and motoneuron membrane resistivity. Exp. Neurol. 1: 491-527.

Ramon y Cajal, S. (1892) The Structure of the Retina, Thomas, Springfield, IL.

Ramon y Cajal, S. (1929) Development of the constituent elements of the retina. In Studies in Vertebrate Neurogenesis, chap. 18, L. Smith, trans., pp. 353-363, Thomas, Springfield, IL.

Saito, H. (1983) Morphology of physiologically identified X-, Y- and W-type retinal ganglion cells of the cat. J. Comp. Neurol. 221: 279288.

Sherman, S. M. (1985) Functional organization of the $W-, X-$, and Y-cell pathways in the cat: A review and hypothesis. In Progress in Psychobiology and Physiological Psychology, vol. 11, J. M. Sprague and A. N. Epstein, eds., pp. 233-314, Academic, Orlando, FL.

Smith, R. G., M. A. Freed, and P. Sterling (1986) Microcircuitry of the dark-adapted cat retina. I. Functional architecture of the rod-cone network. J. Neurosci. 6: 3505-3517.

Stanford, L. R., and S. M. Sherman (1984) Structure-function relationships of retinal ganglion cells in the cat. Brain Res. 297: 381-386.

Sterling, P. (1983) Microcircuitry of the cat retina. Annu. Rev. Neurosci. $6: 149-85$.

Sterling, P., and L. A. Lampson (1986) Molecular specificity of defined types of amacrine synapse in cat retina. J. Neurosci. 6: 1314-1324.

Sterling, P., M. A. Freed, and R. G. Smith (1988) Architecture of rod and cone circuits to the on-beta ganglion cell. J. Neurosci. 8: 623642.

Stevens, J. K., and G. L. Gerstein (1976) Spatio-temporal organization of cat lateral geniculatc receptive fields. J. Neurophysiol. 39: 213238.

Stevens, J. K., B. A. McGuire, and P. Sterling (1980a) Toward a functional architecture of the retina: Serial reconstruction of adjacent ganglion cells. Science 207: 317-319.

Stevens, J. K., T. L. Davis, N. Friedman, and P. Sterling (1980b) A systematic approach to reconstructing microcircuitry by electron microscopy of serial sections. Brain. Res. Rev. 2: 265-293.

Stone, J. (1965) A quantitative analysis of the distribution of ganglion cells in the cats retina. J. Comp. Neurol. 124: 337-353.

Vaney, D. I. (1985) The morphological and topographic distribution of AII amacrine cells in the cat retina. Proc. R. Soc. Lond. [Biol.] 224: $475-488$.

Wässle, H., and H. J. Riemann (1978) The mosaic of nerve cells in the mammalian retina. Proc. R. Soc. [Biol.] 200: 441-461.

Wässle, H., L. Peichl, and B. B. Boycott (1981) Morphology and topography of on- and off-alpha cells in the cat retina. Proc. R. Soc. Lond. [Biol.] 212: 157-175.

Watanabe, M., Y. Fukuda, C.-F. Hsiao, and H. Ito (1985) Electron microscope analysis of amacrine and bipolar cell inputs on $\mathrm{Y}$-, Xand W-cells in the cat retina. Brain Res. 358: 229-240. 